Journal of Contemporary Research in Social Sciences

ISSN : 2641-0249

Vol. 2, No. 5, pp. 89-118

2020

Publisher: Learning Gate

DOI: 10.33094/26410249.2020.25.89.118

(C) 2020 by the authors; licensee Learning Gate

\title{
Job Satisfaction Measurement Tool for Public Sector Executives Case Study: Customs Officers in Greece
}

\author{
Konstantinos M. Karyotakis \\ School of Production Engineering and Management, Technical University of Crete, Chania, Greece. \\ Email: karyotakisk@gmail.com \\ Eleni I. Barda \\ Director of Larisa Customs, Independent Authority for Public Revenue, Larisa, Greece. \\ Email: elina72barda@gmail.com
}

Received: 10 September 2020; Revised: 2 October 2020; Accepted: 16 October 2020; Published: 27 October 2020

\begin{abstract}
Job satisfaction constitutes a significant section of research because it is connected to many direct and indirect consequences of an organization. In a constantly changing environment, where the financial situation sets its own restrictions, factors which increase job satisfaction are sought without wanting to receive monetary gain. As a case study, primary data was gathered from a questionnaire filled out by the Customs Officers (public servants) of Greece. A random sample of six hundred and seventy-nine (679) public employees responded to the questionnaire. The data was processed and analyzed through the IBM SPSS (Statistical Package for Social Science) and grouped by new hyper variables, as a result of Factor Analysis. The results showed that, apart from the financial factors (in which the present study does not refer to), employees derive contentment from work participation, nature of work, value of recognition, evaluation, promotion, and good relations between colleagues and manager. The degree of satisfaction gained from each category is different, and in most cases is open to improvement. Leaders are invited to seek ways to develop each category listed above by specifying which needs the most attention and changing certain practices in place, driving to organizational change and transformation. All in all, by putting into practice the suggestions listed above, a solution can be found without added financial costs, and will ultimately benefit the work situation for civil servants, the economy, and society.
\end{abstract}

Keywords: Public administration, Customs Officers, Job satisfaction, Employees' perceptions, Organizational change, Change management, Organizational culture, Survey instrument, Factor Analysis, Exploratory Factor Analysis.

\section{Introduction}

Employee job satisfaction has been studied for over seventy years and continues to be an important area of research interest to this day. The main reasons for this interest are the effects of job satisfaction on work-related behavior (Eyupoglu \& Saner, 2009) and the fact that improving the financial size of organizations has been shown to be associated with improved job satisfaction (Aronson, Laurenceau, Sieveking, \& Bellet, 2005; Eyupoglu \& Saner, 2009).

The working conditions have completely changed, both in the private and in the public sector, over the past few decades. Pressure from rising labour demands, the economic crisis of recent years, unemployment rates, declining wages, changing pension criteria, the widespread use of computers and the internet are some of the huge changes that have taken place.

So, more and more research is being done internationally to capture the level of job satisfaction. The purpose of this research is the creation of a methodological tool that measures job satisfaction, assessing the degree of job satisfaction experienced by public sector executives and in particular the Greek Customs Officers and, drawing safe conclusions. 
In particular, relationships, connections and hidden parameters that affect the psychology of employees, the degree of this effect, as well as the effects it brings, are sought. In this study, the specifics of the industry were taken into account, as well as the structures of the public sector in Greece.

The customs officials of the Independent Public Revenue Authority (formerly the Ministry of Finance) are confronted with most of the imposed changes in the Greek state. At the same time, they are burdened with increasing revenue (through targets), resulting in significant pressure.

In a sample of six hundred and seventy-nine (679) participants, from most of the Greek Customs Units (even the most remote ones), the findings of this research are particularly important in theory and statistically significant in practice. The added value of this work concerns the proof that the activation of some intrinsic incentives, through changes in existing structures and mentalities, is able to increase the job satisfaction of employees, without cost, providing positive correlations in all related areas.

The following sections cover the research methodology, the compilation of the questionnaire, its coding, the process of sharing and collecting it. Presented are the empirical results, the profile of the participants, the results of the factor analysis, as well as the Pearson correlation analysis. Then, the outcome of the Factor analysis, as well as the Cronbach a reliability test are recorded. Finally, the conclusions of the present research are drawn, its limitations, as well as suggestions for future research on the issue are presented.This study contributes to the existing literature adds a piece to the puzzle of knowledge about the satisfaction that public servants derive from their work.

As we go through a prolonged period of crisis (economic, covid-19, etc.) the Customs Service was chosen as a case study as it is, perhaps, the most important source of revenue of the state budget for raising public revenues (with all that this implies for the economy, society, etc.) while at the same time there is a bibliographic gap in recording and evaluating the views of its executives, which gap is being filled by the present study.

\section{Research Methodology}

\subsection{Method}

In order to record the degree of satisfaction with the work of public sector executives, a methodological tool (questionnaire) was created to collect primary data, from a sufficient number of executives in a relatively short time. Karyotakis and Moustakis (2017) typically report that civil servants, although they are the backbone of public administration, often do not question their views and are therefore not taken into account in formulating an organization's policies and strategies.

To address this phenomenon, the present methodological tool was used to extract information directly from the backbone of public administration. Smye and Cooke (1994) emphasize the importance of human resources for the survival of any organism. The questionnaire ensures anonymity (something that was pointed out) and objectivity, as all participants answer the same questions. Also, the completion of the questionnaires was optional (which was also emphasized). Completing it did not require much time (so as not to bother the employees too much), while it could be completed and sent outside the Service to the attached address stated in the cover letter.

Finally, it should be noted that this methodological tool was used as the answers from a questionnaire can be easily quantified and analyzed with the appropriate statistical tool. Some questionnaires that were not completed were not included in the sample data. The collection of questionnaires took place in the period from 01/02/2016 to 30/04/2016.

\subsection{Participants}

All current Greek customs officials were invited to participate in the investigation. In order to carry out this investigation, the Secretary General of Customs and Special Consumption Taxes was initially informed, who expressed her consent. In the first stage, a pre-test and pilot application of the questionnaire (Mitchell, 1966; Schuman, 1966) was performed on 20 people to identify any problems and ambiguities, in order to ensure its quality (quality assurance). The results were positive and encouraging, so no changes were made to the created tool (questionnaire). 
1,500 questionnaires were printed (including the 20 pilot test questionnaires) that were mailed to all Greek Customs, along with relevant information (cover letter) for the survey. In many cases there was also telephone communication. It was also sent via e-mail (e-mail) to another 200 customs officials. In total, 1,700 questionnaires were submitted (in printed and electronic form).

A period of one (1) month was given for the sending of the questionnaires, which was extended to plus another month in order to collect everything. In order to increase the response rate, several strategies were used, which included anonymity of the respondent, a relevant personal cover letter - an invitation from the researcher himself and a reminder via e-mail, fax or telephone (Karyotakis, 2019).

The completed questionnaires were sent to back by mail (conventional or electronic). The final questionnaires were a total of six hundred and seventy-nine (679), including the 20 pilot survey questionnaires. The response rate is $40 \%$. In this way, the goal of collecting as many questionnaires as possible was achieved with the participation of even the most remote customs offices throughout Greece. In similar surveys of civil servants in Greece, Karyotakis (2019) reported a response rate of 34.14\% and Zampetakis (2007) 34.6\%.

\subsection{Questionnaire Control}

For the design of the questionnaire, after studying articles from the international literature on job satisfaction, the measurement tools described in Table 1. The combined instruments (multiple questions) used in this question were used. Cross-sectional study has already been developed by other researchers.It has been observed that research tools, which have already been used in other research, have many benefits, because through their application, their reliability and validity have been improved and re-evaluated (Gibbon, 1995). However, several revisions and adjustments have been made, so that the created tool is impartial and applicable to executives of the Greek public administration. Initially, a pool of objects was created, which was based on definitions and already designed scales, and then quantitative and qualitative measurements (pretests) were made (Karyotakis, 2019).

The scale used for these measurements is the 7-point Likert scale (closed-ended questions), from 1 to 7, evaluating a corresponding quality rating scale from "Absolutely disagree" to "Absolutely agree". The 7-point scale was chosen to allow for greater discrimination.

All questions were artfully scattered throughout the questionnaire. For best outcome, the process of double-back translation was followed, from English (original source) to Greek (target language) and vice versa (from target language to source), by skilled and experienced translators, independently, without being aware of the previous questionnaire (blind translation) (Karyotakis, 2019); (Brislin, Lonner, \& Thorndike, 1973; Werner \& Campbell, 1970). The questions were compared and adapted to the specifics of the Greek public administration (localization), confirming the adequacy and equivalent meaning (Karyotakis, 2019).

Table-1.

Organizational Characteristics.

\begin{tabular}{l|c|c}
\hline \multirow{2}{*}{ Internal work environment } & \multicolumn{2}{|c}{ Definition of variables } \\
\cline { 2 - 2 } & Number of questions (items) & Operational Definition \\
\hline Salary & 5 & \\
\hline Other working benefits & 5 & \multirow{2}{*}{ (Spector, 1994) } \\
\hline Relations among colleagues & 4 & \\
\hline Relations with manager & 3 & \\
\hline Value recognition & 4 & \multirow{2}{*}{ (Devi \& Suneja, 2013) } \\
\hline Promotion & 7 & \\
\hline Nature labour & 4 & \\
\hline Work Participation & &
\end{tabular}




\begin{tabular}{l|c|c}
\hline \multirow{2}{*}{ Internal work environment } & \multicolumn{2}{|c}{ Definition of variables } \\
\cline { 2 - 3 } & Number of questions (items) & Operational Definition \\
\hline Efficiency evaluation & 3 & (Park \& Rainey, 2007) \\
\hline Total factors evaluation & 9 & \\
\hline Total & 49 & \\
\hline
\end{tabular}

For the Total Evaluation of the measurement of satisfaction by all the above groups of factors criteria (pay, other work benefits, relationships with colleagues, relationships with supervisor, nature of work, work participation, value recognition, promotion, performance, end evaluation), a group of questions, in order to record the total satisfaction (globally) that the respondents received for each of the above groups. In other words, nine questions were created, each of which concerned the overall satisfaction that the respondent received from each group. The 7-point Likert scale was used here as well, from 1- "Absolutely dissatisfied" to -7 "Absolutely satisfied".

At the beginning of the Questionnaire included questions about gender, age, marital status, level of education, job, years of service, monthly income (as well as (Karyotakis, 2019)), which are important demographic characteristics used as control variables in the job satisfaction literature. Also, a question was asked about any knowledge of a foreign language, in order to check if and to what extent this feature also plays a role in the satisfaction that customs officials receive from their work environment, since the specifics of this profession usually require knowledge of a foreign language in order to be able to communicate with citizens - traders of foreign countries.

\subsection{Coding of Questionnaire Questions}

For easier understanding of tables and results, the following Tables (Table 2 - Table 10) are presented, with the coding of the questions per group of variables. Table 2 presents the coding question for "Remuneration", Table 3 presents "Other working benefits", Table 4 concerns to "Relations among colleagues" and Table 5 examines "Relations with supervisor". In addition, Table 6 has to do with the "Nature labour", Table 7 deals with "Work participation" and Table 8 scrutinizes "Other working benefits". Last but not least, Table 9 explores the coding question for "Promotion" and Table 10 probes "Efficiency evaluation".

Table-2.

Coding Questions for Remuneration.

\begin{tabular}{l|l}
\hline I feel I am being paid a fair amount for the work I do. & Payment 1 \\
\hline Raises are too few and far between. & Payment 2 \\
\hline $\begin{array}{l}\text { I feel unappreciated by the organization when I think about what they pay } \\
\text { me. }\end{array}$ & Payment 3 \\
\hline I feel satisfied with my chances for salary increases. & Payment 4 \\
\hline I don't feel my efforts are rewarded the way they should be. & Payment 5 \\
\hline
\end{tabular}

Table-3.

Coding Questions for Other working benefits.

I am not satisfied with the benefits I receive.

The benefits we receive are as good as most other organizations offer.

The benefit package we have is equitable.

There are few rewards for those who work here.

There are benefits we do not have which we should have.

\begin{tabular}{l} 
Benefit 1 \\
\hline Benefit 2 \\
\hline Benefit 3 \\
\hline Benefit 4 \\
\hline Benefit 5
\end{tabular}


Table-4.

Coding Questions for Relations among colleagues.

\begin{tabular}{l|l}
\hline I like the people I work with. & Colleagues 1 \\
\hline Communications seem good within this organization. & Colleagues 2 \\
\hline $\begin{array}{l}\text { I find I have to work harder at my job because of the incompetence } \\
\text { of people I work with. }\end{array}$ & Colleagues 3 \\
\hline I enjoy my coworkers. & Colleagues 4 \\
\hline There is too much bickering and fighting at work. & Colleagues 5 \\
\hline
\end{tabular}

Table-5.

Coding Questions for Relations with supervisor.

\begin{tabular}{l|l}
\hline My supervisor is quite competent in doing his/her job. & Manager 1 \\
\hline My supervisor is unfair to me. & Manager 2 \\
\hline My supervisor shows too little interest in the feelings of subordinates. & Manager 3 \\
\hline I like my supervisor. & Manager 4 \\
\hline
\end{tabular}

Table-6.

Coding Questions for Nature labour.

\begin{tabular}{l|l}
\hline $\begin{array}{l}\text { I am satisfied with how often I create new ideas, procedures or } \\
\text { things. }\end{array}$ & Nature of Work 1 \\
\hline I am satisfied with how often I perform detailed tasks. & Nature of Work 2 \\
\hline I feel good about how my work can benefit other people. & Nature of Work 3 \\
\hline $\begin{array}{l}\text { I am able to improve my work skills because of the feedback I } \\
\text { get about the job. }\end{array}$ & Nature of Work 4 \\
\hline I can fully display my abilities in this job. & Nature of Work 5 \\
\hline My job requires a good mix of my skills. & Nature of Work 6 \\
\hline I get a sense of satisfaction from the work I do. & Nature of Work 7
\end{tabular}

Table-7.

Coding Questions for Work participation.

\begin{tabular}{l|l}
\hline I am satisfied with how often I take part in problem solving. & Participation 1 \\
\hline In my job, I am satisfied with how often I share knowledge with & Participation 2 \\
others. & \\
\hline In my job, I am satisfied with how often I persuade others. & Participation 3 \\
\hline I can identify how I contributed to various projects / & Participation 4 \\
assignments.
\end{tabular}

Table-8.

Coding Questions for Value recognition.

\begin{tabular}{l|l}
\hline When I do a good job, I receive the recognition for it that I should receive. & Value 1 \\
\hline I do not feel that the work I do is appreciated. & Value 1 \\
\hline I feel a sense of pride in doing my job. & Value 1 \\
\hline
\end{tabular}

Table-9.

Coding Questions for Promotion.

There is really too little chance for promotion on my job.

Those who do well on the job stand a fair chance of being promoted.

People get ahead as fast here as they do in other places.

I am satisfied with my chances for promotion.

\begin{tabular}{l} 
Promotion 1 \\
\hline Promotion 2 \\
\hline Promotion 3 \\
\hline Promotion 4 \\
\hline
\end{tabular}

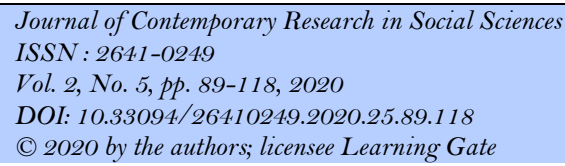


Table-10.

Coding Questions for Efficiency evaluation.

\begin{tabular}{l|l}
\hline The standards used to evaluate my performance are fair. & Evaluation 1 \\
\hline I have sufficient opportunities (such as challenging tasks or projects) & Evaluation 2 \\
to earn a high-performance rating. & \\
\hline I am satisfied with my organization's performance appraisal system. & Evaluation 3 \\
\hline
\end{tabular}

\section{Experimental Results}

\subsection{Introduction}

Data were coded and analyzed using IBM SPSS (Statistical Package for Social Science), version 23. Frequencies of responses, Pearson Correlations, Factor Analysis and Exploratory Factor Analysis (EFA) were performed.

\subsection{Profile of Participants}

The total number of the sample is 679 people. Data were recorded on gender, age, level of education, knowledge of a foreign language, marital status, personal income, work experience and job position. The profile of the participants is outlined in Table 11.

Table-11.

Personal information (demographic characteristics) ( $\mathrm{n}=679)$.

\begin{tabular}{|c|c|c|c|}
\hline Sex & $\%$ & Foreign Language & $\%$ \\
\hline Male & 48,9 & Yes & 67,2 \\
\hline Female & 51,1 & No & 32,5 \\
\hline \multicolumn{2}{|l|}{ Age } & \multicolumn{2}{|l|}{ Marital Status } \\
\hline $25-35$ & 10,0 & Singles & 20,5 \\
\hline $36-45$ & 39,9 & Married & 15,5 \\
\hline $46-55$ & 31,4 & Married With Children & 53,5 \\
\hline $56-65$ & 17,4 & Divorced & 7,8 \\
\hline $66+$ & 1,3 & Widows & 2,7 \\
\hline \multicolumn{2}{|l|}{ Educational Level } & \multicolumn{2}{|c|}{ Years of Service in Customs } \\
\hline Secondary Education & 18,9 & Up To 5 & 18 \\
\hline Technological Education & 19,0 & $6-15$ & 29,2 \\
\hline University Education & 46,2 & $16-26$ & 28 \\
\hline Postgraduate & 15,9 & $27+$ & 24,7 \\
\hline \multicolumn{2}{|l|}{ Job Position } & \multicolumn{2}{|c|}{ Monthly Income (Net Personal) } \\
\hline White Collar Worker & 80 & Up To $1.000 €$ & 8,8 \\
\hline Head Devision & 16,5 & $1.001-1.500 €$ & 48,7 \\
\hline Deputy Director & 0,7 & $1.501-2.000 €$ & 32,7 \\
\hline \multirow[t]{2}{*}{ Director } & 2,7 & $2.001-2.500 €$ & 5,3 \\
\hline & & $>2.500 €$ & 4,4 \\
\hline
\end{tabular}

\subsection{Factor Analysis}

Table 12 below presents the variables used in the present survey, with the answers of the respondents on the specific variables, in percentages, for each possible answer from 1 (Absolutely disagree) to 7 (Absolutely agree), averages and standard deviations. 
Table-12.

\begin{tabular}{|c|c|c|c|c|c|c|c|c|c|}
\hline Variables & $\begin{array}{c}\text { Absolutely } \\
\text { Disagree }\end{array}$ & $\begin{array}{l}\text { Strongly } \\
\text { Disagree }\end{array}$ & $\begin{array}{c}\text { Slightly } \\
\text { Disagree }\end{array}$ & Neutral & $\begin{array}{c}\text { Slightly } \\
\text { Agree }\end{array}$ & $\begin{array}{c}\text { Strongly } \\
\text { Agree }\end{array}$ & $\begin{array}{c}\text { Absolutely } \\
\text { Agree }\end{array}$ & Average & SD \\
\hline Payment 1 & $18.9 \%$ & $24.3 \%$ & $13.5 \%$ & $9.4 \%$ & $14.6 \%$ & $12.8 \%$ & $6.5 \%$ & 3.4 & 1.924 \\
\hline Payment 2 & $9 \%$ & $2.4 \%$ & $2.7 \%$ & $5.4 \%$ & $5.6 \%$ & $15.9 \%$ & $59.1 \%$ & 5.8 & 1.922 \\
\hline Payment 3 & $19.3 \%$ & $13.3 \%$ & $8.2 \%$ & $25.9 \%$ & $10.6 \%$ & $12.5 \%$ & $10.2 \%$ & 3.73 & 1.951 \\
\hline Payment 4 & $43 \%$ & $23.1 \%$ & $9.1 \%$ & $10 \%$ & $4.6 \%$ & $6.3 \%$ & $3.8 \%$ & 2.44 & 1.764 \\
\hline Payment 5 & $6.2 \%$ & $6.2 \%$ & $6.3 \%$ & $13.7 \%$ & $11.6 \%$ & $28.6 \%$ & $27.4 \%$ & 5.14 & 1.818 \\
\hline Benefit 1 & $4.6 \%$ & $6.8 \%$ & $11.5 \%$ & $13.7 \%$ & $14.7 \%$ & $24 \%$ & $24.7 \%$ & 4.98 & 1.781 \\
\hline Benefit 2 & $12.4 \%$ & $15.8 \%$ & $12.7 \%$ & $28.6 \%$ & $8.1 \%$ & $12.2 \%$ & $10.3 \%$ & 3.82 & 1.828 \\
\hline Benefit 3 & $28.9 \%$ & $22.8 \%$ & $14.6 \%$ & $10.6 \%$ & $9.7 \%$ & $8.4 \%$ & $5 \%$ & 2.95 & 1.854 \\
\hline Benefit 4 & $5.2 \%$ & $6 \%$ & $9.4 \%$ & $16.1 \%$ & $13 \%$ & $24.7 \%$ & $25.6 \%$ & 5.02 & 1.784 \\
\hline Benefit 5 & $3.5 \%$ & $2.8 \%$ & $2.8 \%$ & $8.2 \%$ & $9.7 \%$ & $27.5 \%$ & $45.4 \%$ & 5.82 & 1.560 \\
\hline Colleagues 1 & $2.4 \%$ & $3.8 \%$ & $5.2 \%$ & $18.4 \%$ & $24 \%$ & $32.3 \%$ & $14 \%$ & 5.11 & 1.409 \\
\hline Colleagues2 & $16.5 \%$ & $14 \%$ & $14 \%$ & $12.2 \%$ & $17.5 \%$ & $18.7 \%$ & $7.1 \%$ & 3.85 & 1.930 \\
\hline Colleagues3 & $11.6 \%$ & $12.2 \%$ & $8.2 \%$ & $20.9 \%$ & $16.5 \%$ & $17.5 \%$ & $13 \%$ & 4.23 & 1.898 \\
\hline Colleagues4 & $3.1 \%$ & $5.9 \%$ & $10.5 \%$ & $24.6 \%$ & $21.6 \%$ & $24 \%$ & $10.3 \%$ & 4.69 & 1.500 \\
\hline Colleagues5 & $11.9 \%$ & $19.7 \%$ & $12.8 \%$ & $16.5 \%$ & $23.9 \%$ & $9 \%$ & $6.2 \%$ & 3.72 & 1.753 \\
\hline Manger 1 & $4.9 \%$ & $4.7 \%$ & $8.5 \%$ & $14.1 \%$ & $17.2 \%$ & $28 \%$ & $22.5 \%$ & 5.08 & 1.692 \\
\hline Manger2 & $33 \%$ & $22.7 \%$ & $11.2 \%$ & $14.6 \%$ & $7.5 \%$ & $6.6 \%$ & $4.4 \%$ & 2.78 & 1.804 \\
\hline Manger3 & $25.3 \%$ & $20.9 \%$ & $10.3 \%$ & $17.2 \%$ & $8.5 \%$ & $9.3 \%$ & $8.4 \%$ & 3.24 & 1.965 \\
\hline Manger4 & $2.9 \%$ & $3.8 \%$ & $2.4 \%$ & $27.1 \%$ & $14 \%$ & $28.1 \%$ & $21.6 \%$ & 5.16 & 1.518 \\
\hline Nature W 1 & $10.8 \%$ & $16.2 \%$ & $10.3 \%$ & $21.6 \%$ & $19.6 \%$ & $15.3 \%$ & $6.2 \%$ & 3.94 & 1.756 \\
\hline Nature W 2 & $7.2 \%$ & $9.9 \%$ & $10.3 \%$ & $16.2 \%$ & $23.1 \%$ & $26.4 \%$ & $6.9 \%$ & 4.45 & 1.691 \\
\hline Nature W 3 & $2.1 \%$ & $4.4 \%$ & $5.4 \%$ & $14.3 \%$ & $15.8 \%$ & $32.8 \%$ & $25 \%$ & 5.45 & 2.776 \\
\hline Nature W 4 & $6.6 \%$ & $7.7 \%$ & $9.4 \%$ & $26.2 \%$ & $27.1 \%$ & $15.3 \%$ & $7.7 \%$ & 4.36 & 1.563 \\
\hline Nature W 5 & $10.9 \%$ & $19.3 \%$ & $12.4 \%$ & $13.7 \%$ & $20.9 \%$ & $14.7 \%$ & $8.1 \%$ & 3.91 & 1.844 \\
\hline Nature W 6 & $1.3 \%$ & $2.9 \%$ & $3.2 \%$ & $8.2 \%$ & $20.5 \%$ & $32.5 \%$ & $31.2 \%$ & 5.66 & 1.352 \\
\hline Nature W 7 & $3.1 \%$ & $9.3 \%$ & $6.6 \%$ & $16.6 \%$ & $28.9 \%$ & $24 \%$ & $11.5 \%$ & 4.77 & 1.553 \\
\hline Participat.1 & $6.3 \%$ & $7.5 \%$ & $9 \%$ & $16.9 \%$ & $23.4 \%$ & $28.9 \%$ & $8 \%$ & 4.62 & 1.638 \\
\hline Participat.2 & $3.2 \%$ & $8.5 \%$ & $7.8 \%$ & $16.5 \%$ & $22.4 \%$ & $30.9 \%$ & $10.6 \%$ & 4.81 & 1.571 \\
\hline Participat.3 & $6.3 \%$ & $4.7 \%$ & $8.7 \%$ & $21.6 \%$ & $27.5 \%$ & $23.1 \%$ & $8 \%$ & 4.61 & 1.549 \\
\hline Participat.4 & $0.9 \%$ & $1.9 \%$ & $3.8 \%$ & $15.5 \%$ & $23.4 \%$ & $34.8 \%$ & $19.7 \%$ & 5.42 & 1.259 \\
\hline
\end{tabular}




\begin{tabular}{c|c|c|c|c|c|c|c|c|c}
\hline Value 1 & $7.4 \%$ & $14 \%$ & $9.9 \%$ & $16.8 \%$ & $23.4 \%$ & $22.8 \%$ & $5.7 \%$ & 4.26 & 1.709 \\
\hline Value 2 & $9 \%$ & $22.1 \%$ & $14.1 \%$ & $18.3 \%$ & $16.8 \%$ & $12.8 \%$ & $6.9 \%$ & 3.78 & 1.759 \\
\hline Value 3 & $1.8 \%$ & $2.2 \%$ & $1.8 \%$ & $18.3 \%$ & $19 \%$ & $28.4 \%$ & $28.6 \%$ & 5.50 & 1.384 \\
\hline Promotion 1 & $4.7 \%$ & $10.9 \%$ & $10.3 \%$ & $22.1 \%$ & $16.1 \%$ & $18.6 \%$ & $17.4 \%$ & 4.59 & 1.757 \\
\hline Promotion2 & $22.8 \%$ & $19.9 \%$ & $14.7 \%$ & $14.9 \%$ & $12.8 \%$ & $11.9 \%$ & $2.9 \%$ & 3.23 & 1.809 \\
\hline Promotion3 & $8.5 \%$ & $10.6 \%$ & $11.6 \%$ & $44.5 \%$ & $11.5 \%$ & $8.7 \%$ & $4.6 \%$ & 3.84 & 1.470 \\
\hline Promotion4 & $18.6 \%$ & $18.6 \%$ & $13.3 \%$ & $27.4 \%$ & $10.3 \%$ & $8.2 \%$ & $3.7 \%$ & 3.32 & 1.688 \\
\hline Evaluation 1 & $25.9 \%$ & $27.4 \%$ & $17.2 \%$ & $15.2 \%$ & $7.2 \%$ & $4.9 \%$ & $2.2 \%$ & 2.74 & 1.574 \\
\hline Evaluation2 & $23.6 \%$ & $26.5 \%$ & $16.1 \%$ & $18.1 \%$ & $9.1 \%$ & $5 \%$ & $1.6 \%$ & 2.84 & 1.563 \\
\hline Evaluation3 & $30.6 \%$ & $25.2 \%$ & $14.9 \%$ & $16.5 \%$ & $7.2 \%$ & $3.8 \%$ & $1.8 \%$ & 2.63 & 1.557 \\
\hline
\end{tabular}




\subsubsection{Answers Regarding Payment}

Carrying out a regularity test for the group of questions concerning the satisfaction that customs officials receive from their "Remuneration" Table 13 it is observed that for the first question, mean> media $(3.41>3)$, revealing a positive asymmetry in the sample (distribution sideways to the right). Therefore, the largest percentage of participants (56.7\%) answered 1-3 (ie disagrees) to this question. In questions 2 and 3 , mean <media $(5.80<7 \& 3.73<4)$ is observed. The distance from the middle value is disproportionately large and negative, so the distribution is oblique to the left - negative asymmetry. In the second question, $80.6 \%$ of the participants agree that "raises are too few and far between".

In the $4^{\text {th }}$ question mean $>$ media $(2.44>2)$, there is a positive asymmetry in the sample (distribution sideways to the left, with a concentration of answers from 1: I completely disagree with 3: I disagree a little). $72 \%$ are not satisfied with the opportunities for salary increase. In the 5 th question mean $<$ media $(5.14<6)$, there is a negative asymmetry with $67.6 \%$ of the participants answering between 5 : I agree a little to 7: I completely agree "I don't feel that my efforts are rewarded the way they should be".

In conclusion, it can be said that the "Remuneration", as a factor of job satisfaction, is not satisfactory to the extent that the Greek customs officials would like.

Table-13.

Regularity test for the group of questions concerning the satisfaction that customs officials receive from their "Remuneration". Statistics

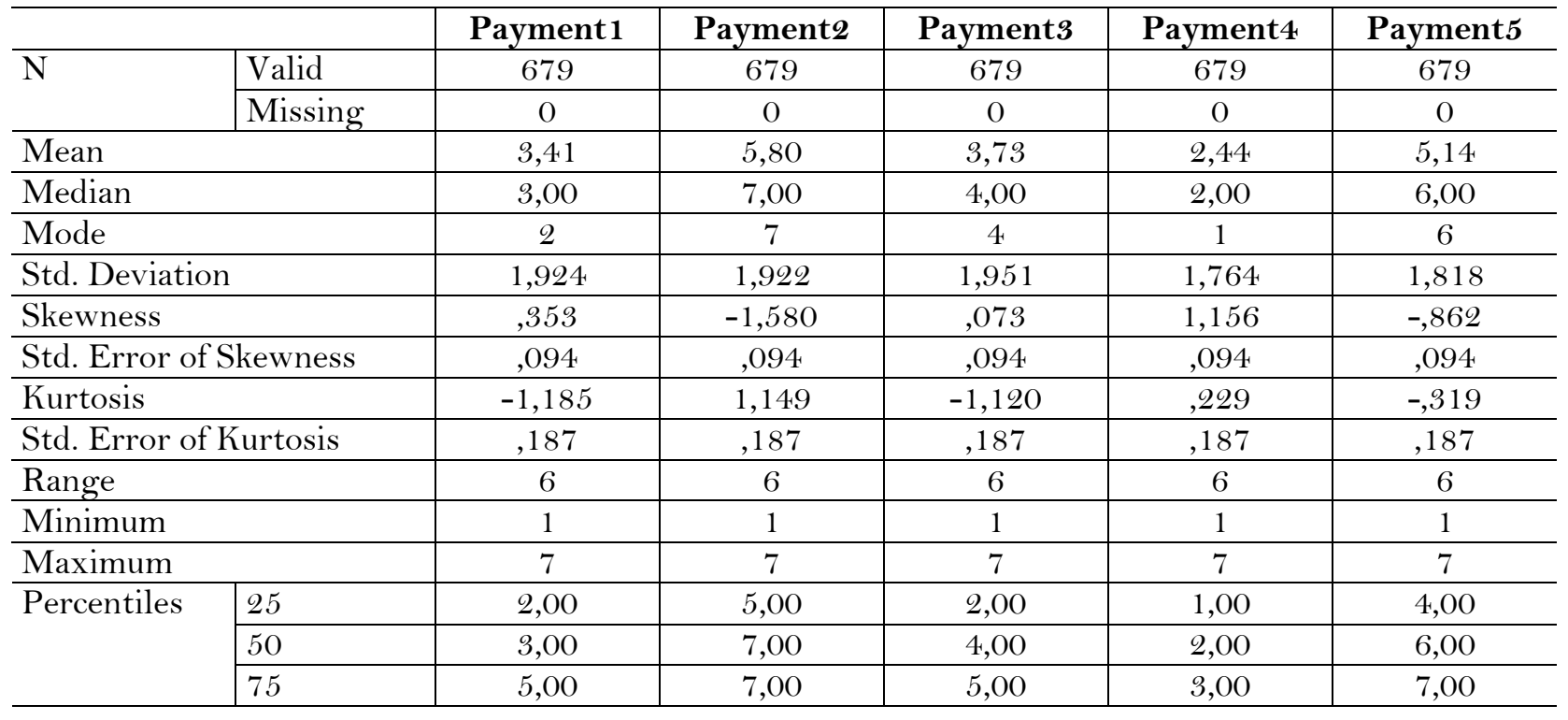

\subsubsection{Answers References with the Other Working Benefits}

Carrying out a regularity test for the group of questions concerning the satisfaction that the customs officials receive from the "Other work benefits" Table 14 it is observed that for the 1 st and 2nd question, mean $<$ media $(4.98<5 \& 3.82<4$ respectively), so there is a negative asymmetry in the sample (distribution sideways to the left). $63.4 \%$ of the participants answered that they are not satisfied with the benefits they receive.

In the 3 question, mean> media $(2.95>2)$, there is a positive asymmetry in the sample (distribution sideways to the right), so a large percentage of responses range from 1 to 3 (ie disagreement). $66.3 \%$ state that "the benefit package we have is NOT equitable" to the work we do. In the 4th and 5 th questions, means media ( $5.02<6 \& 5.82<6$ respectively), there is a negative asymmetry. 
$63.3 \%$ of the participants in the 4 th question gave answers from $5-7$, i.e. they agree that there are few rewards for customs employees. 83.6\% (second largest percentage recorded) believe that "there are benefits that we do not have which we should have".

In conclusion, it is observed that the "Other labour benefits", as a factor of job satisfaction, do not satisfy to the extent that they would like the customs officials of Greece.

Table-14.

Regularity test for the group of questions concerning the satisfaction that customs officials receive from the "Other work benefits".

Statistics

\begin{tabular}{|c|c|c|c|c|c|c|}
\hline & Benefit 1 & Benefit2 & Benefit3 & Benefit4 & Benefit5 \\
\hline \multirow[t]{2}{*}{$\mathrm{N}$} & Valid & 679 & 679 & 679 & 679 & 679 \\
\hline & Missing & $\mathrm{O}$ & $\mathrm{O}$ & $\mathrm{O}$ & $\mathrm{O}$ & $\mathrm{O}$ \\
\hline \multicolumn{2}{|l|}{ Mean } & 4,98 & 3,82 & 2,95 & 5,02 & 5,82 \\
\hline \multicolumn{2}{|l|}{ Median } & 5,00 & 4,00 & 2,00 & 6,00 & 6,00 \\
\hline \multicolumn{2}{|l|}{ Mode } & 7 & 4 & 1 & 7 & 7 \\
\hline \multicolumn{2}{|c|}{ Std. Deviation } & 1,781 & 1,828 & 1,854 & 1,784 & 1,560 \\
\hline \multicolumn{2}{|c|}{ Skewness } &,- 608 &, 149 & ,688 &,- 667 & $-1,571$ \\
\hline \multicolumn{2}{|c|}{ Std. Error of Skewness } & ,094 & ,094 & ,094 & ,094 & ,094 \\
\hline \multicolumn{2}{|l|}{ Kurtosis } &,- 692 &,- 926 &,- 704 &,- 574 & 1,863 \\
\hline \multicolumn{2}{|c|}{ Std. Error of Kurtosis } &, 187 &, 187 &, 187 &, 187 &, 187 \\
\hline \multicolumn{2}{|l|}{ Range } & 6 & 6 & 6 & 6 & 6 \\
\hline \multicolumn{2}{|l|}{ Minimum } & 1 & 1 & 1 & 1 & 1 \\
\hline \multicolumn{2}{|l|}{ Maximum } & 7 & 7 & 7 & 7 & 7 \\
\hline \multirow[t]{3}{*}{ Percentiles } & 25 & 4,00 & 2,00 & 1,00 & 4,00 & 5,00 \\
\hline & 50 & 5,00 & 4,00 & 2,00 & 6,00 & 6,00 \\
\hline & 75 & 6,00 & 5,00 & 4,00 & 7,00 & 7,00 \\
\hline
\end{tabular}

\subsubsection{Answers References to the Relationships with Colleagues}

By conducting a regularity test for the group of queries regarding the satisfaction of customs officials with "relationships with colleagues" Table 15 it is observed that in contrast to previous responses (pay and other work benefits), there are a number of questions about peer relationships with positive attitude. $70.3 \%$ say "I like the people I work with". However, opinions differ on the customs communication system, with $44.5 \%$ saying it does not work well and $43.3 \%$ disagreeing.

In the 3 rd question mean $>$ media $(4.23>4)$, there is a positive asymmetry in the sample, with $47 \%$ stating "I find I have to work harder at my job because of the incompetence of people I work with". In 5 th and in the 6th question all the answers express a satisfaction. $55.9 \%$ enjoy the relations with his associates, while $44.4 \%$ disagree that "there is too much bickering and fighting at work".

In conclusion, it is observed that the "relations with the colleagues", as a factor of job satisfaction, satisfy, to the extent that they would like, the customs officers of Greece. There is an identification of conclusions with Davis (2013) where the good atmosphere in the workplace creates a chain of commitment and union, which brings satisfaction to employees and maximum performance.

\subsubsection{Answers References to the Relationships with Supervisor}

Carrying out a regularity test for the question group regarding the satisfaction that customs officials receive from "Relationship with Supervisor", there is also a positive attitude (as in relations with colleagues). $67.7 \%$ of participants agree that "My supervisor is quite competent in doing his/her job". Here, mean $<$ media $(5.8<6)$, so there is a negative asymmetry in the sample. 
Table-15.

Regularity test for the group of questions concerning the satisfaction that customs officials receive from "Colleagues".

Statistics

\begin{tabular}{|c|c|c|c|c|c|c|}
\hline & & Colleag 1 & Colleage & Colleag3 & Colleag4 & Colleag5 \\
\hline \multirow[t]{2}{*}{$\mathrm{N}$} & Valid & 679 & 679 & 679 & 679 & 679 \\
\hline & Missing & $\mathrm{O}$ & $\mathrm{O}$ & $\mathrm{O}$ & $\mathrm{O}$ & $\mathrm{O}$ \\
\hline \multicolumn{2}{|l|}{ Mean } & 5,11 & 3,85 & 4,23 & 4,69 & 3,72 \\
\hline \multicolumn{2}{|l|}{ Median } & 5,00 & $4, \mathrm{OO}$ & 4,00 & 5,00 & $4, \mathrm{OO}$ \\
\hline \multicolumn{2}{|l|}{ Mode } & 6 & 6 & 4 & 4 & 5 \\
\hline \multicolumn{2}{|c|}{ Std. Deviation } & 1,409 & 1,930 & 1,898 & 1,500 & 1,753 \\
\hline \multicolumn{2}{|l|}{ Skewness } &,- 836 &,- 059 &,- 237 &,- 439 &, 050 \\
\hline \multicolumn{2}{|c|}{ Std. Error of Skewness } & ,094 & ,094 & ,094 & ,094 & ,094 \\
\hline \multicolumn{2}{|l|}{ Kurtosis } & ,460 & $-1,277$ & $-1,048$ &,- 342 & $-1,033$ \\
\hline \multicolumn{2}{|c|}{ Std. Error of Kurtosis } &, 187 &, 187 &, 187 &, 187 &, 187 \\
\hline \multicolumn{2}{|l|}{ Range } & 6 & 6 & 6 & 6 & 6 \\
\hline \multicolumn{2}{|l|}{ Minimum } & 1 & 1 & 1 & 1 & 1 \\
\hline \multicolumn{2}{|l|}{ Maximum } & 7 & 7 & 7 & 7 & 7 \\
\hline \multirow[t]{3}{*}{ Percentiles } & 25 & 4,00 & 2,00 & 3,00 & $4, \mathrm{OO}$ & 2,00 \\
\hline & 50 & 5,00 & 4,00 & 4,00 & 5,00 & 4,00 \\
\hline & 75 & 6,00 & 6,00 & 6,00 & 6,00 & 5,00 \\
\hline
\end{tabular}

In the 2 nd and 3rd questions, $66.9 \%$ and $56.5 \%$, respectively, state "my supervisor is unfair to me" and "my supervisor shows too little interest in the feelings of subordinates". Finally, in the 4th question, $63.7 \%$ state "I like my supervisor". Notable is the $27.1 \%$ of participants who state "I am neutral" and show a large percentage of people who are not emotionally involved with other people from their workplace.

In conclusion, "Relations with Supervisor", as a factor of job satisfaction, satisfies, to some extent, the Greek Customs officials, but can be improved.

Table-16.

Regularity test for the group of questions concerning the satisfaction that customs officials receive from "Supervisor".

Statistics

\begin{tabular}{|c|c|c|c|c|c|}
\hline \multicolumn{2}{|l|}{ 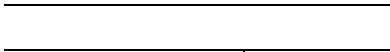 } & Manager 1 & Managere & Manager3 & Manager4 \\
\hline \multirow[t]{2}{*}{$\mathrm{N}$} & Valid & 679 & 679 & 679 & 679 \\
\hline & Missing & $\mathrm{O}$ & $\mathrm{O}$ & $\mathrm{O}$ & $\mathrm{O}$ \\
\hline \multicolumn{2}{|l|}{ Mean } & 5,08 & 2,78 & 3,24 & 5,16 \\
\hline \multicolumn{2}{|l|}{ Median } & 6,00 & 2,00 & 3,00 & 5,00 \\
\hline \multicolumn{2}{|l|}{ Mode } & 6 & 1 & 1 & 6 \\
\hline \multicolumn{2}{|c|}{ Std. Deviation } & 1,692 & 1,804 & 1,965 & 1,518 \\
\hline \multicolumn{2}{|l|}{ Skewness } &,- 795 &, 788 & , 488 &,- 717 \\
\hline \multicolumn{2}{|c|}{ Std. Error of Skewness } & ,094 & ,094 & ,094 & ,094 \\
\hline \multicolumn{2}{|c|}{ Kurtosis } &,- 204 &,- 477 &,- 988 & ,086 \\
\hline \multicolumn{2}{|c|}{ Std. Error of Kurtosis } &, 187 &, 187 &, 187 &, 187 \\
\hline \multicolumn{2}{|l|}{ Range } & 6 & 6 & 6 & 6 \\
\hline \multicolumn{2}{|l|}{ Minimum } & 1 & 1 & 1 & 1 \\
\hline \multicolumn{2}{|l|}{ Maximum } & 7 & 7 & 7 & 7 \\
\hline \multirow[t]{3}{*}{ Percentiles } & 25 & $4, \mathrm{OO}$ & $1, \mathrm{OO}$ & 1,00 & $4, \mathrm{OO}$ \\
\hline & 50 & 6,00 & 2,00 & 3,00 & 5,00 \\
\hline & 75 & 6,00 & 4,00 & 5,00 & 6,00 \\
\hline
\end{tabular}




\subsubsection{Answers Regarding to the Nature of Work}

Carrying out a regularity test for the question group regarding the satisfaction that customs officials receive from the "Nature of the Job" Table 17 a positive attitude was observed again (as well as with relationships with colleagues and supervisor). In all the questions (7 questions) of this group, all the mean values are less than the mean (mean <media). So, there is a negative asymmetry. The percentages in all the questions of those who agree range between $41.1 \%$ to $84 \%$.

Noteworthy is the $73.6 \%$ in the 3 rd question where there is an agreement that "I feel good about how my work can benefit other people", as well as the $84 \%$ where they agree that "my job requires a good mix of my skills". That means the combination of many different skills. $84 \%$ as a percentage (from 5: Slightly agree to 7: Absolutely agree) is the highest percentage that has been collected in this questionnaire.

It is concluded that the "Nature of labour", as a factor of job satisfaction, largely satisfies the customs officers of Greece: There is an identification of views with Wright and Davis (2003), who conclude that the special characteristics of the workplace affect the satisfaction derived from it.

Very important is the contribution of Andersen and Kjeldsen (2010) who demonstrate the uniqueness of each part of the public sector and claim that job satisfaction also depends on the organizational work produced by the service, which is observed in the present study.

Table -17.

Regularity test for the group of questions concerning the satisfaction that customs officials receive from the "Nature of the Job".

Statistics

\begin{tabular}{|c|c|c|c|c|c|c|c|c|}
\hline & Nature 1 & Nature2 & Nature3 & Nature4 & Nature5 & Nature6 & Nature7 \\
\hline \multirow[t]{2}{*}{$\mathrm{N}$} & Valid & 679 & 679 & 679 & 679 & 679 & 679 & 679 \\
\hline & Missing & $\mathrm{O}$ & $\mathrm{O}$ & $\mathrm{O}$ & $\mathrm{O}$ & $\mathrm{O}$ & $\mathrm{O}$ & $\mathrm{O}$ \\
\hline \multicolumn{2}{|l|}{ Mean } & 3,94 & 4,45 & 5,45 & 4,36 & 3,91 & 5,66 & 4,77 \\
\hline \multicolumn{2}{|l|}{ Median } & $4, \mathrm{OO}$ & 5,00 & 6,00 & 5,00 & 4,00 & 6,00 & 5,00 \\
\hline \multicolumn{2}{|l|}{ Mode } & 4 & 6 & 6 & 5 & 5 & 6 & 5 \\
\hline \multicolumn{2}{|c|}{ Std. Deviation } & 1,756 & 1,691 & 2,776 & 1,563 & 1,844 & 1,352 & 1,553 \\
\hline \multicolumn{2}{|c|}{ Skewness } &,- 118 &,- 534 & 15,168 &,- 426 &,- 019 & $-1,248$ &,- 628 \\
\hline \multicolumn{2}{|c|}{ Std. Error of Skewness } & ,094 & ,094 & ,094 & ,094 & ,094 & ,094 & ,094 \\
\hline \multicolumn{2}{|c|}{ Kurtosis } & $-1,014$ &,- 701 & 334,145 &,- 301 & $-1,182$ & 1,472 &,- 267 \\
\hline \multicolumn{2}{|c|}{ Std. Error of Kurtosis } &, 187 &, 187 &, 187 &, 187 &, 187 &, 187 &, 187 \\
\hline \multicolumn{2}{|l|}{ Range } & 6 & 6 & 65 & 6 & 6 & 6 & 6 \\
\hline \multicolumn{2}{|c|}{ Minimum } & 1 & 1 & 1 & 1 & 1 & 1 & 1 \\
\hline \multicolumn{2}{|c|}{ Maximum } & 7 & 7 & 66 & 7 & 7 & 7 & 7 \\
\hline \multirow{3}{*}{$\begin{array}{l}\text { Percent } \\
\text { iles }\end{array}$} & 25 & 2,00 & 3,00 & 4,00 & 4,00 & 2,00 & 5,00 & 4,00 \\
\hline & 50 & 4,00 & 5,00 & 6,00 & 5,00 & $4, \mathrm{OO}$ & 6,00 & 5,00 \\
\hline & 75 & 5,00 & 6,00 & 7,00 & 5,00 & $5, \mathrm{OO}$ & 7,00 & 6,00 \\
\hline
\end{tabular}

\subsubsection{Answers Regarding to Work Participation}

Carrying out a regularity check for the question group regarding the satisfaction that the customs officials receive from the "Work Participation" Table 18 and here a positive result is observed. In all the questions (in all 4 questions) of this group, all the mean values are less than the mean (mean <media). In other words, it is a negative asymmetry (oblique to the left). The percentages of those who agree range from $58.6 \%$ to $77.9 \%$.

Employees are satisfied with how often they engage in problem solving, with how often they share their knowledge with others, with how often they persuade others, and with how much they have contributed to various assignment tasks. 
In conclusion, it is observed that the "Labour Participation", as a factor of job satisfaction, largely satisfies the customs officials of Greece.

Table-18.

Regularity test for the group of questions concerning the satisfaction that customs officials receive from the "Work Participation".

\section{Statistics}

\begin{tabular}{|c|c|c|c|c|c|}
\hline \multirow{3}{*}{$\mathrm{N}$} & & Participation1 & Participation2 & Participation3 & Participation4 \\
\hline & Valid & 679 & 679 & 679 & 679 \\
\hline & Missing & O & $\mathrm{O}$ & $\mathrm{O}$ & 0 \\
\hline \multicolumn{2}{|l|}{ Mean } & 4,62 & 4,81 & 4,61 & 5,42 \\
\hline \multicolumn{2}{|l|}{ Median } & 5,00 & 5,00 & $5, \mathrm{OO}$ & 6,00 \\
\hline \multicolumn{2}{|l|}{ Mode } & 6 & 6 & 5 & 6 \\
\hline \multicolumn{2}{|c|}{ Std. Deviation } & 1,638 & 1,571 & 1,549 & 1,259 \\
\hline \multicolumn{2}{|l|}{ Skewness } &,- 670 &,- 683 &,- 668 &,- 844 \\
\hline \multicolumn{2}{|c|}{ Std. Error of Skewness } & ,094 & ,094 & ,094 & ,094 \\
\hline \multicolumn{2}{|l|}{ Kurtosis } &,- 397 &,- 329 &,- 032 & ,682 \\
\hline \multicolumn{2}{|c|}{ Std. Error of Kurtosis } &, 187 & 187 & 187 &, 187 \\
\hline \multicolumn{2}{|l|}{ Range } & 6 & 6 & 6 & 6 \\
\hline \multicolumn{2}{|l|}{ Minimum } & 1 & 1 & 1 & 1 \\
\hline \multicolumn{2}{|l|}{ Maximum } & 7 & 7 & 7 & 7 \\
\hline \multirow[t]{3}{*}{ Percentiles } & 25 & $4, \mathrm{OO}$ & $4, \mathrm{OO}$ & $4, \mathrm{OO}$ & 5,00 \\
\hline & 50 & 5,00 & 5,00 & 5,00 & 6,00 \\
\hline & 75 & 6,00 & 6,00 & 6,00 & 6,00 \\
\hline
\end{tabular}

Table-19.

Regularity test for the group of questions concerning the satisfaction that customs officials receive from the

"Value Recognition".

\section{Statistics}

\begin{tabular}{|c|c|c|c|c|}
\hline & & Value1 & Valueq & Values \\
\hline \multirow[t]{2}{*}{$\mathrm{N}$} & Valid & 679 & 679 & 679 \\
\hline & Missing & $\mathrm{O}$ & $\mathrm{O}$ & $\mathrm{O}$ \\
\hline \multicolumn{2}{|l|}{ Mean } & 4,26 & 3,78 & 5,50 \\
\hline \multicolumn{2}{|l|}{ Median } & 5,00 & 4,00 & 6,00 \\
\hline \multicolumn{2}{|l|}{ Mode } & 5 & 2 & 7 \\
\hline \multicolumn{2}{|c|}{ Std. Deviation } & 1,709 & 1,759 & 1,384 \\
\hline \multicolumn{2}{|l|}{ Skewness } &,- 386 &, 145 &,- 940 \\
\hline \multicolumn{2}{|c|}{ Std. Error of Skewness } & ,094 & ,094 & ,094 \\
\hline \multicolumn{2}{|l|}{ Kurtosis } &,- 923 & $-1,052$ &, 754 \\
\hline \multicolumn{2}{|c|}{ Std. Error of Kurtosis } &, 187 &, 187 &, 187 \\
\hline \multicolumn{2}{|l|}{ Range } & 6 & 6 & 6 \\
\hline \multicolumn{2}{|l|}{ Minimum } & 1 & 1 & 1 \\
\hline \multicolumn{2}{|l|}{ Maximum } & 7 & 7 & 7 \\
\hline \multirow[t]{3}{*}{ Percentiles } & 25 & 3,00 & 2,00 & 5,00 \\
\hline & 50 & 5,00 & 4,00 & 6,00 \\
\hline & 75 & 6,00 & 5,00 & 7,00 \\
\hline
\end{tabular}

\subsubsection{Answer Answers with Value Recognition}

By conducting a regularity test for the group of questions concerning the satisfaction that customs officials receive from "Value Recognition" Table 19 satisfied employees are again identified. In all the

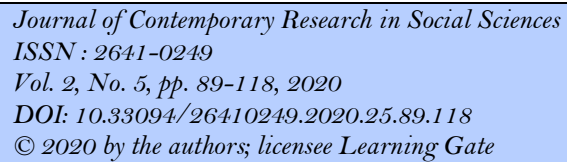


questions of this group (in all 3 questions), all the mean values are less than the mean (mean $<$ media). In other words, there is a negative asymmetry (oblique to the left). Satisfaction rates are high, with more than $76 \%$ agreeing to the 3rd question: "I feel a sense of pride in doing my job".

In conclusion, it seems that the "Value Recognition", as a factor of job satisfaction, satisfies to a large extent, the customs officials of Greece.

\subsubsection{Answers Regarding to the Promotion}

Conducting a regularity check for the question group regarding the satisfaction that customs officials receive from the "Promotion" Table 20 there is a strong dissatisfaction. In the 1st and 3rd questions, mean $<$ media $(4.59<5 \& 3.84<4$ respectively). Therefore, there is a negative asymmetry in the sample. $52.1 \%$ of participants state that "There is really too little chance for promotion on my job".

In the 3rd question, $44.5 \%$ state neutrality in the question: "People progress as fast in our service as in other services". This is explained by the fact that in order to answer this question one must know how the promotion system works in all other public sector services. This knowledge usually does not exist, so the most logical answer is neutrality.

In the 2 nd and 4th question, mean $>$ media $(3.23>3 \& 3.32>3$ respectively). So, there is a positive asymmetry. $57.4 \%$ of employees disagree that "Those who do well on the job stand a fair chance of being promoted". Also, 50.4\% is not satisfied with the promotion opportunities.

In conclusion, it is observed that the possibility of "Promotion", as a factor of job satisfaction, does not satisfy to the extent that the Greek customs officials would like.

Table-2o.

Regularity test for the group of questions concerning the satisfaction that customs officials receive from the "Promotion".

Statistics

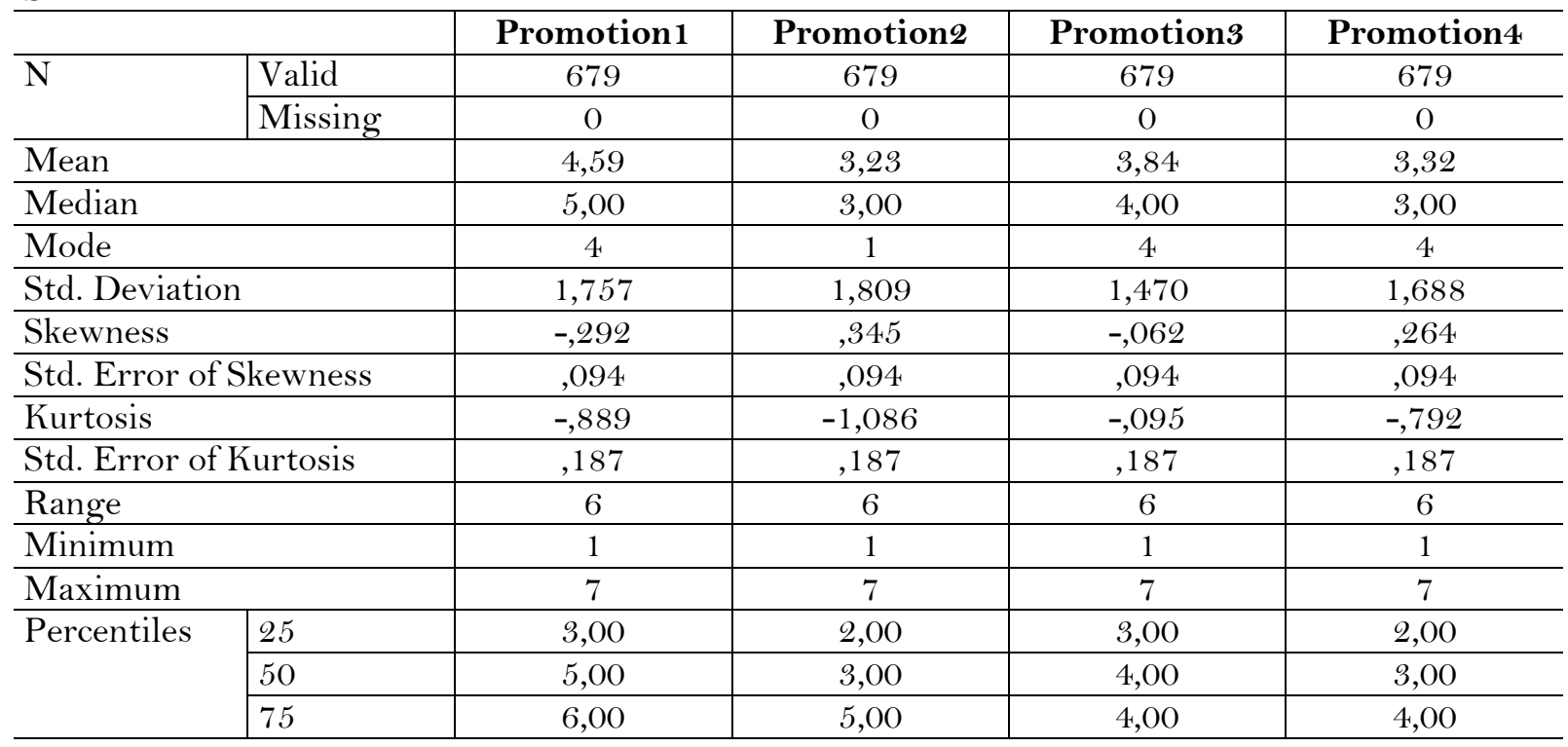

\subsubsection{Answers Regarding to the Evaluation Criteria}

By conducting a regularity test for the group of questions concerning the satisfaction that customs officials receive from the "Evaluation Criteria" Table 21 the results are negative. Specifically, it is observed that in all $3 \mathrm{~s}$ questions mean $(2.74>2,2.84>2,2.63>2)$. So, there is a positive asymmetry in the sample. Employees with $70.5 \%, 66.2 \%$ and $70.7 \%$, respectively, responded that they disagreed with the fact that "the standards used to evaluate my performance are fair", "I have sufficient opportunities (such as challenging tasks or projects) to earn a high performance rating" and "I am satisfied with my organization's performance appraisal system" of my service. 
In conclusion, it seems that the "Evaluation criteria", as a factor of job satisfaction, does not satisfy to the extent that they would like the customs officials of Greece.

Table-21.

Regularity test for the group of questions concerning the satisfaction that customs officials receive from the "Evaluation Criteria".

\section{Statistics}

\begin{tabular}{l|l|c|c|c}
\hline \multicolumn{2}{l}{$\mathrm{N}$} & Evaluation1 & Evaluation2 & Evaluation3 \\
\hline & Valid & 679 & 679 & 679 \\
\cline { 2 - 5 } & Missing & 0 & 0 & 0 \\
\hline Mean & 2,74 & 2,84 & 2,63 \\
\hline Modian & 2,00 & 2,00 & 2,00 \\
\hline Std. Deviation & 2 & 2 & 1 \\
\hline Skewness & 1,574 & 1,563 & 1,557 \\
\hline \multicolumn{2}{l|}{ Std. Error of Skewness } &, 791 &, 607 &, 782 \\
\hline Kurtosis &, 094 &, 094 &, 094 \\
\hline Std. Error of Kurtosis &,- 129 &,- 478 &,- 188 \\
\hline Range &, 187 &, 187 &, 187 \\
\hline Minimum & 6 & 6 & 6 \\
\hline Maximum & 1 & 1 & 1 \\
\hline \multirow{2}{*}{ Percentiles } & 25 & 7 & 7 & 7 \\
\cline { 2 - 5 } & 50 & 1,00 & 2,00 & 1,00 \\
\cline { 2 - 5 } & 75 & 2,00 & 2,00 & 2,00 \\
\hline
\end{tabular}

\subsection{Pearson Correlation Analysis}

The Pearson correlation coefficient indicates the linear relationship between two variables (interval or scale). It is a numerical measure (or index of size) of the correlation between two sets of values. It ranges in size from -1.00 to +1.00 , exceeding 0.00 . A positive sign " $+"$ means a positive correlation (that is, the values of one variable increase when the values of the other increase). A negative sign means negative correlation (that is, the values of one variable increase as the values of the other decrease). A correlation factor of 1.00 means that there is a perfect correlation between the two variables.

In other words, a scatter plot of the two variables will show that all points are perfectly aligned in a straight line. A value of 0.00 means that the points of the scatter plot are randomly distributed around any straight line drawn or arranged so that they approach a curve (Martin, 1978; Siomkos \& Vasilikopoulou, 2005).

\subsubsection{Pearson Correlation Analysis for Association of Questions: Payment - Education - Income - Service - Position}

An analysis was made of the correlation of the questions related to remuneration, education, income, previous service and the job position. It was observed that there is a strong positive correlation (coefficient 0.098*) between the level of education and the question "raises are too few and far between".

That is, the higher the level of education, the stronger the belief that increases are minimal and slow. The double-direction significance test confirms that the correlation between the two variables is statistically significant, at a statistical significance level of $\alpha=0.005$.

Also, there is a positive correlation (coefficient $0.084^{*}$ ) between income and the question that states that the salary they receive for their work is fair. The (positive) correlation shows that as people's income increases, so does their belief that the pay they receive for their work is fair. Statistical significance level $\alpha=0.005$. 
There is a very strong positive correlation (coefficient $0.054^{* *}$ ) between income and job satisfaction opportunities. As their income increases both increase their satisfaction with the opportunities for salary increases. Statistical significance level $\alpha=0.001$.

Finally, a very strong negative correlation (coefficient $-0,102^{* *}$ ) was observed between education and job satisfaction opportunities. In particular, the more educated a person is, the less satisfaction there is with the opportunities for salary increases. Statistical significance level $\alpha=0.001$.

\subsubsection{Pearson Correlation Analysis for Association of Questions: Other Working Benefits - Education - Income-} Work Experience - Position

Subsequently, an analysis was made of the correlation of the questions concerning the other work benefits, education, income, previous service and the job position. It was observed that there is a very strong positive correlation (coefficient $0.149^{* *}$ ) between income and the belief that the benefit package from the work provided is fair to it. That is, as people's income increases, so does the belief that the benefit package from work is fair. Statistical significance level $\alpha=0.001$.

Finally, there is a strong positive correlation (0.082* ratio) between job and the belief that there are no benefits to work that should exist. The higher the level of the person, the greater the belief that there are no benefits from work that should exist. Statistical significance level a $=0.005$.

\subsubsection{Pearson Correlation Analysis for Association of Questions: Relationships with Colleagues - Education -} Income - Work Experience - Position

Regarding to questions concerning relations with colleagues, education, income, seniority and employment, the correlation analysis showed the following:

There is a very strong positive correlation (coefficient $0.113^{* *}$ ) between income and the belief that the communication system in the service works well. Statistical significance level a $=0.001$.

Regarding the years of service and the belief of employees that they work harder due to the incompetence of some of their associates, a very strong positive correlation was found (coefficient 0.105). As people work at the Customs (the older they are), the more they believe they are working harder because of the incompetence of some of their associates. Statistical significance level a $=0.001$.

\subsubsection{Pearson Correlation Analysis for the Correlation of Questions: Relationship with Supervisor-Education- Income - Previous Service - Job Position}

The correlation analysis in the questions related to the relationship with the supervisor, education, income, previous service and job showed that there is a very strong positive correlation (coefficient $\left.0.100^{* *}\right)$ between income and the belief that the supervisor shows little interest for the feelings of his subordinates. As people's income increases, so does that belief. Statistical significance level $\alpha=0.001$.

A very strong negative correlation (coefficient -0.079**) is observed between previous service and the belief that supervisors are not skilled enough in their job. As people's working years increase (the older they get), the more they embrace that belief. Statistical significance level $\alpha=0.001$.

Between previous service and the question of whether the supervisors are unfair to the employees, a strong positive correlation was observed (rate 0.082*). As people's working years increase (the older they get), the more they believe that their supervisors are unfair to them. Statistical significance level $\alpha$ $=0.005$.

Previous service has been associated with very strong positives (coefficient $0.118^{* *}$ ) with the suggestion that supervisors show little interest in the feelings of their subordinates. As the number of years of work of individuals increases (the older they are), the more they believe that the above sentence is true. Level of statistical significance $\mathrm{a}=0.001$.

Finally, the years of service are associated with very strong negatives (coefficient $-0.115^{* *}$ ) in terms of sympathy in the face of their supervisor. As people's work years increase (the older they get), the more they don't like their supervisor. Statistical significance level $\alpha=0.001$. 
It is generally observed that employees with many years of service show a negative attitude towards their supervisors. They don't consider them capable; they don't think they care for their subordinates and they are unjust. In the public sector, as in the military, there is the informal hierarchy of years of service as well as age.

Clearly, then, it seems to be bothering older people (in years and years of service) to be headed by new employees with fewer years of service but obviously more formal qualifications.

\subsubsection{Pearson Correlation for Association of Questions: Nature of Work - Education - Income- Work Experience - Position}

With regard now to questions concerning the nature of work, education, income, seniority and employment, the correlation analysis showed that:

There is a very strong negative correlation (coefficient $-0,131^{*} *$ ) between the level of education and support from work. The higher the level of education of individuals, the less they believe that they receive support from work to improve it. Statistical significance levels a - 0.001.

There is a strong negative correlation $\left(-0.081^{*}\right)$ between the level of training and utilization of the skills of employees. The higher the level of education of individuals, the less they believe that they can make full use of their abilities. Statistical significance level $\alpha=0.005$.

There is a very strong positive correlation (coefficient $0.196^{* *}$ ) between income and perception of the creation of new ideas, processes and things. As people's income increases, so does the sense of satisfaction with creating new ideas. Statistical significance level $\alpha=0.001$.

The income is very strongly correlated positively (rate $0.129^{* *}$ ) with the perception of doing detailed work. As people's income increases, so does the sense of satisfaction with doing detailed work. Statistical significance level $\alpha=0.001$.

There is a very strong positive correlation $\left(0.140^{* *}\right)$ between income and perception of employee utilization. As people's income increases, so does the sense that individuals can fully demonstrate their abilities. Statistical significance level $\alpha=0.001$.

As the years of service increase (the older one is) the more satisfaction one gets from creating new ideas and processes (at a rate $0.141^{* *}$ ), the performance of detailed work (with a factor of $0.124^{* *}$ ), the belief that he can fully demonstrate his abilities (with a factor of $0.093^{*}$ ), as well as from the work he does (with a factor of $\left.0.110^{* *}\right)$. The positive correlations are very strong and the statistical significance level $\alpha=0.001$.

Finally, the higher the individual's position in the Service, the greater the satisfaction he receives from doing detailed work (at a rate of $0.097^{*}$ ), from work due to the benefit his work offers to other people (at a rate of $0.111^{* *}$ ), the belief that he can fully demonstrate his skills (with a rate of $0.080^{* *}$ ), due to the mixing of his skills, i.e. the combination of many different skills, in order to be able to successfully meet his duties (with a factor of $0.148^{* *}$ ). The positive correlations are very strong and the statistical significance level $\alpha=0.001$.

\subsubsection{Pearson Correlation for Association of Questions: Work Participation - Education - Income-Work Experience - Position}

Analyzing the correlations in the questions related to work participation, education, income, previous service and job, it was observed that the more educated people are, the more they tend to be more satisfied with their involvement in problem solving (factor $0.079^{*}$ ), as well as how often they share their knowledge with others $0.086^{*}$ ). The positive correlations are strong and the statistical significance level $\alpha=0.005$.

In addition, the higher the income of individuals, the greater the satisfaction they receive from their involvement in problem solving (rate 0.256**), how often they share their knowledge with others, and how often they persuade others; coefficient $0.260^{* *}$ ), as well as their contribution to assignment tasks 
(coefficient $0.172^{* *}$ ). The positive correlations are very strong and the statistical significance level is a 0.001 .

As public service years increase, so does the satisfaction they receive from engaging in problem solving (rate $0.176^{* *}$ ), how often do they share their knowledge with others, and how often do they persuade others (coefficient $0.224^{*}$ ), as well as their contribution to assignment tasks (coefficient $\left.0.191^{* *}\right)$. The positive correlations are very strong and the statistical significance level $\alpha=0.001$.

Finally, the higher the position of an employee, the greater the satisfaction he receives from his involvement in problem solving (factor 0.229**), than how often he shares his knowledge with others (factor $0.186^{* *}$ ), than how often he persuades others (rate 0.220**), as well as his contribution to assignment tasks (factor $\left.0.200^{* *}\right)$. The positive correlations are very strong and the statistical significance level $\alpha=0.001$.

\subsubsection{Pearson Correlation Analysis for Association of Questions: Recognition of Value - Education - Income- Work Experience-Job Position}

The correlation analysis on the questions related to value recognition, education, income, seniority and employment demonstrates a strong negative correlation (factor $-0.097^{*}$ ) between education and the perception that by doing a job well an employee will receive the proper recognition. The higher the level of education of individuals, the more they tend not to believe that doing their job well will receive the recognition they deserve. Statistical significance level $\alpha=0.005$.

As people's income increases, they believe that doing their job well will increase their recognition (rate $0.110^{* *}$ ) and increase their pride (their self-esteem) for what they do (factor $0.086^{* *}$ ). The positive correlations are very strong and the statistical significance level $\alpha=0.001$.

There is a very strong positive correlation (coefficient $0.146^{* *}$ ) between years of previous service and pride in work. As the years of service increase (the older one gets), the prouder one is about work, the more one feels good about one's job. Level of statistical significance $a=0.001$.

The higher the level of people, the more they tend to think that by doing their job well they will receive high recognition (coefficient $0.117^{* * *}$ ), appreciation for their work (coefficient $0.110^{* *}$ ) and pride (coefficient $0.145^{*}$ ). The correlations are positive and very strong and the statistical significance level $\alpha=0.001$.

\subsubsection{Pearson Correlation for Association of Questions: Progression - Education - Income - Work Experience -} Job Position

Nowadays, when it comes to promotion, education, income, seniority and employment, the correlation analysis shows that the higher a person's income, the more they believe that those who do their job well have opportunities for promotion (strong positive correlation, coefficient 0.093*, at the level of statistical significance $\alpha=0.005$ ) and receive increased satisfaction from these opportunities (very strong positive correlation with coefficient $0.157^{* *}$, at the level of statistical significance $\alpha=$ 0.001 ).

As the number of years of service increases (the older one is), the more satisfying the opportunities for promotion. This is a very strong positive correlation (coefficient 0.101**), with a statistical significance level $\alpha=0.001$.

There is a very strong negative correlation between job and probability (small) for promotion (rate $\left.0.084^{*}\right)$. The higher one is, the less likely one is to be promoted. It makes sense since $\mathrm{s} /$ he is judging by his own result, that is, the position of responsibility s/he already occupies. Statistical significance level $\alpha$ $=0.005$.

Finally, the higher one is, the more one tends to think that those who do their job well will be promoted (very strong positive correlation with a coefficient of $0.189^{* *}$, at a statistical significance level of $\alpha=0.001$ ), progressing hierarchically as fast as in the others. services (strong positive correlation with a rate of $0.082^{*}$, at a statistical significance level $\alpha=0.005$ ), and have increased satisfaction with 
opportunities for promotion (very strong positive correlation with a coefficient of $0.247^{*}$, at a statistical significance level $\alpha=0.001)$.

\subsubsection{Pearson Correlation of Association: Standards Evaluation - Education - Income - Work Experience - Job Position}

Analyzing the correlations in the questions related to performance appraisal, education, income, seniority and employment, it was found that the higher the income of individuals, the more appropriate they consider the performance appraisal criteria (coefficient 0.104**), they have opportunities to win higher efficiency (factor $0.101^{* *}$ ) and their satisfaction with the performance appraisal system applied by the service increases (factor $0.113^{* *}$ ). These correlations are very strongly positive, at a statistical significance level of 0.001 .

\subsection{Factor Analysis}

Factor analysis is a technique that requires a large number of samples. According to Tabachnick and Fidell (2011) a sample of 500-1000 is considered "Very Good" while> 1000 "Extremely Good". The sample of the present research, therefore, with the 679 fully answered questionnaires, according to the above, is a very good sample.

In order to reduce the large number of observed variables to a smaller number of important factors (or dimensions), the principal components factor analysis was used. This method is the most widely used one. It identifies the linear combination of variables, so that the factors explain the maximum variability of the variables.

The results of the principal components factor analysis, after the varimax rotation, are presented in Table 22 and Table 23. They were released through the statistical package IBM SPSS (Statistical Package for Social Science), version 23. It should be noted that to successfully implement Factor Analysis there must be a hypothesis that a group of variables can be grouped into a smaller one (Acito, Anderson, \& Engledow, 1980).

As can be seen in the Table 23 below, seven (7) factors have emerged whose values (eigenvalues) exceed the unit and which explain $61.699 \%$ of the total variation. This percentage is acceptable and satisfactory, as it exceeds $50 \%$, which is a limit of the minimum acceptable percentage.

In addition, factor loadings are all statistically significant because they are all greater than 0.5, so they participate as variables in the names of the factors that have corresponded to this analysis (Hair, Black, Babin, Anderson, \& Tatham, 2006).

\subsubsection{Implication of Exploratory Factor Analysis (EFA)}

The Kaiser-Meyer-OIkin (KMO) measure, a measure of competency sampling, provides an estimate of the degree of homogeneity of variables or otherwise to what extent this correlation table is suitable for factor analysis. This ranges between 0 and 1. Acceptable results are greater than 0.55. Here is KMO0.869> 0.55 Table 22. The closer the result tends to be to 1, the better (Siomkos \& Vasilikopoulou, $2005)$.

The first factor groups all the questions for Participation and two questions about the Nature of Work. Specifically, statements related to problem solving, knowledge sharing, discussion and persuasion of colleagues, contribution to assignment tasks, creation of new ideas, procedures and things, as well as detailed work. This factor, therefore, was named: Partwork.

The second factor groups three questions from the Colleagues team and two questions from the Manager team. The questions concern the perception of the customs officers about their colleagues, the communication system at work, the relationship between them, the ability of the supervisors in their role, as well as the feelings of sympathy or dislike they may have for them. This factor is called Colman.

The third factor includes the three questions of the Evaluation team and the fourth question from the Promotion team. The third factor is called Eval. The questions are about the Customs perception of 
their performance appraisal criteria, opportunities for higher performance and their performance appraisal system, as well as to opportunities for promotion.

In the fourth factor, two questions are collected from the Other Working Benefits (Benefit) and one from the Remuneration (Payment). The fourth factor is called Ben.Pay. The questions concern the perception of the customs officers about the benefits they receive, as well as the rewards of their efforts.

The fifth factor, two questions are collected from the Nature of Work team and one from the Value Recognition (Value). The fifth factor is called Vawork. The questions concern the perception of the customs for the mixing of their skills (the combination, that is, many different skills), the taking of a sense of satisfaction from the specific work, as well as you, a sense of pride when the work is done properly.

The sixth factor raises two questions from the Remuneration team, one from the Value group and one from the Promotion team. All the questions here express dissatisfaction and this factor was named Paysat.

In the seventh and last factor two questions are collected from Remuneration team and one of the Other benefits and was named Paypro Table 22.

Table-22.

Index KMO and Bartlett's Test.

\begin{tabular}{l|l|c}
\hline \multicolumn{2}{|c|}{ Kaiser-Meyer-Olkin Measure of Sampling Adequacy } & $\mathbf{0 , 8 6 9}$ \\
\hline \multirow{3}{*}{ Bartlett's Test of Sphericity } & Approx. Chi-Square & 8728,463 \\
\cline { 2 - 3 } & Df & 435 \\
\cline { 2 - 3 } & Sig. & 0,000 \\
\hline
\end{tabular}

Table-23.

Total Variance Results.

Total Variance Explained

\begin{tabular}{|c|c|c|c|c|c|c|c|c|c|}
\hline \multirow[t]{2}{*}{ Component } & \multicolumn{3}{|c|}{ Initial Eigenvalues } & \multicolumn{3}{|c|}{$\begin{array}{c}\text { Extraction Sums of Squared } \\
\text { Loadings }\end{array}$} & \multicolumn{3}{|c|}{$\begin{array}{c}\text { Rotation Sums of Squared } \\
\text { Loadings }\end{array}$} \\
\hline & Total & $\begin{array}{c}\text { \% of } \\
\text { Variance }\end{array}$ & \begin{tabular}{|c|}
$\begin{array}{c}\text { Cumulati } \\
\text { ve } \%\end{array}$ \\
\end{tabular} & Total & $\begin{array}{c}\% \text { of } \\
\text { Variance } \\
\end{array}$ & $\begin{array}{c}\text { Cumulati } \\
\text { ve } \%\end{array}$ & Total & $\begin{array}{c}\text { \% of } \\
\text { Variance }\end{array}$ & \begin{tabular}{|c|}
$\begin{array}{c}\text { Cumulati } \\
\text { ve } \%\end{array}$ \\
\end{tabular} \\
\hline 1 & 7,463 & 24,876 & 24,876 & 7,463 & 24,876 & 24,876 & 4,269 & 14,229 & 14,229 \\
\hline 2 & 3,028 & 10,094 & 34,970 & 3,028 & 10,094 & 34,970 & 3,409 & 11,364 & 25,593 \\
\hline 3 & 2,156 & 7,186 & 42,156 & 2,156 & 7,186 & 42,156 & 3,187 & 10,622 & 36,215 \\
\hline 4 & 1,882 & 6,274 & 48,430 & 1,882 & 6,274 & 48,430 & 2,150 & 7,166 & 43,381 \\
\hline 5 & 1,556 & 5,186 & 53,616 & 1,556 & 5,186 & 53,616 & 1,964 & 6,546 & 49,926 \\
\hline 6 & 1,307 & 4,357 & 57,973 & 1,307 & 4,357 & 57,973 & 1,785 & 5,951 & 55,877 \\
\hline 7 & 1,118 & 3,726 & 61,699 & 1,118 & 3,726 & 61,699 & 1,746 & 5,821 & 61,699 \\
\hline
\end{tabular}

Note: Extraction Method: Principal Component Analysis.

\subsubsection{Results Analysis (EFA)}

Table 24 (Rotated Component Matrix), contains the loads of the factors after the rotation. The factors can be interpreted by this table. However, this process is somewhat subjective, as it is solely at the discretion of each scientist and essentially reflects in this mentality, culture and the researcher's views regarding the problem. It is not uncommon or paradoxical for two or more people to give different interpretations to exactly the same numerical results (Ntio, 2004; Stewart, 1981).

The role of factor analysis in any statistical study is to highlight factors that are deeply hidden and affect the outcome of a problem (issue) or a specific situation. Also, factor analysis provides very important data for the relationships that connect a series of observations - variables. Finally, it can be said that it is a tool for assessing non-measurable factors, but crucial for the development of a situation (Ntio, 2004).

Journal of Contemporary Research in Social Sciences
ISSN : 264.1-0249
Vol. 2, No. 5, pp. $89-118,2020$
DOI: $10.33094 / 26410249.2020 .25 .89 .118$
(C) 2020 by the authors; licensee Learning Gate


Table-24.

EFA Results.

Rotated Component Matrix ${ }^{a}$

\begin{tabular}{|c|c|c|c|c|c|c|c|}
\hline & \multicolumn{7}{|c|}{ Component } \\
\hline & 1 & 2 & 3 & 4 & 5 & 6 & 7 \\
\hline Participation 1 & 0,834 & & & & & & \\
\hline Participation 2 & 0,814 & & & & & & \\
\hline Participation3 & 0,812 & & & & & & \\
\hline Nature Of Work2 & 0,750 & & & & & & \\
\hline Participation4 & 0,580 & & & & & & \\
\hline Nature Of Work 1 & 0,538 & & & & & & \\
\hline Colleagues 1 & & 0,830 & & & & & \\
\hline Colleagues4 & & 0,788 & & & & & \\
\hline Manager 1 & & 0,745 & & & & & \\
\hline Manager4 & & 0,714 & & & & & \\
\hline Colleagues 2 & & 0,653 & & & & & \\
\hline Evaluation3 & & & 0,848 & & & & \\
\hline Evaluation 1 & & & 0,825 & & & & \\
\hline Evaluation2 & & & 0,776 & & & & \\
\hline Promotion4 & & & 0,609 & & & & \\
\hline Benefit4 & & & & 0,773 & & & \\
\hline Benefit 1 & & & & 0,748 & & & \\
\hline Payment5 & & & & 0,665 & & & \\
\hline Nature of Work7 & & & & & 0,727 & & \\
\hline Nature of Work6 & & & & & 0,703 & & \\
\hline Value3 & & & & & 0,548 & & \\
\hline Payment2 & & & & & & 0,581 & \\
\hline Payment3 & & & & & & 0,556 & \\
\hline Value2 & & & & & & 0,552 & \\
\hline Promotion 1 & & & & & & 0,552 & \\
\hline Payment 1 & & & & & & & 0,680 \\
\hline Payment4 & & & & & & & 0,680 \\
\hline Benefit3 & & & & & & & 0,599 \\
\hline
\end{tabular}

Table 25 presents the grouping of variables and the creation of new hyper-variables, resulting from the factor analysis.

\subsubsection{Partwork}

Satisfaction from active participation in the work environment emerged as a very important factor. Executives feel satisfied when they are called upon to make decisions, persuade partners and actively contribute to problem solving (Kaiser, 2014). In particular, the first three variables Participation $(1,2,3)$ receive very high values $(>0,800)$. This means that the employee feels satisfied when $\mathrm{s} /$ he takes on leadership roles, diagnoses problems and passes on his know-how to those around him.

The next two variables Nature of Work $(1,2)$ indicate that the employee is satisfied when $\mathrm{s} / \mathrm{he}$ is creative. New ideas, procedures and things innovative, but also detailed assignments that require specialization and perhaps passion, lead the employee to high job satisfaction rates (Wright \& Davis, 2003). 
Table-25.

Grouping of variables and new hyper-variables.

\begin{tabular}{|c|c|}
\hline \multirow[t]{6}{*}{ Partwork } & Participation 1 \\
\hline & Participation 2 \\
\hline & Participation 3 \\
\hline & Nature of Work 2 \\
\hline & Participation 4 \\
\hline & Nature of Work 1 \\
\hline \multirow[t]{5}{*}{ Colman } & Colleagues 1 \\
\hline & Colleagues 4 \\
\hline & Manager 1 \\
\hline & Manager 4 \\
\hline & Colleagues 2 \\
\hline \multirow[t]{4}{*}{ Eval } & Evaluation 3 \\
\hline & Evaluation 1 \\
\hline & Evaluation 2 \\
\hline & Promotion 4 \\
\hline \multirow[t]{3}{*}{ Ben.Pay } & Benefit 4 \\
\hline & Benefit 1 \\
\hline & Payment 5 \\
\hline \multirow[t]{3}{*}{ Vawork } & Nature of Work 7 \\
\hline & Nature of Work 6 \\
\hline & Value 3 \\
\hline \multirow[t]{4}{*}{ Paysat } & Payment 2 \\
\hline & Payment 3 \\
\hline & Value 2 \\
\hline & Promotion 1 \\
\hline \multirow[t]{3}{*}{ Paypro } & Payment 1 \\
\hline & Payment 4 \\
\hline & Benefit 3 \\
\hline
\end{tabular}

\subsubsection{Colman}

Relationships in the workplace, both with colleagues and with the supervisor, emerged as very important factors in this hyper-variable. Specifically, the variables Colleague $(1,2,4)$ and Manager $(1,4)$ indicate human sociability in the workplace (Davis, 2013).

Having good relationships with people with whom you spend at least eight hours a day (at Customs due to shifts, the hours are much longer and the conditions are special, such as borders, airports, ports, etc.), as well as having a good code of communication and cooperation, it leads to high levels of satisfaction.

The employee expects the supervisor to take on the role assigned to her/him. She/he wants to believe that $\mathrm{s} /$ he is capable and worthy of the position $\mathrm{s} /$ he holds, so that $\mathrm{s} /$ he feels safe and secure in her/his own role (Voon, Lo, Ngui, \& Ayob, 2011).

\subsubsection{Eval}

A very important factor was the criteria used to evaluate performance in the workplace. Employees feel satisfied when they think they are being judged fairly and with the right tools. Merit in ratings is a factor of great satisfaction as it receives very high prices (> 0.800), Evaluation (3.1). 
The next two variables Evaluation 3 and Promotion 4 show that a fair and objective assessment that will lead to a corresponding promotion in a position of responsibility, are conditions that will lead to great job satisfaction (Batiou \& Valkanos, 2013; Kaiser, 2014).

\subsubsection{Ben.Pay}

The fourth factor has high loadings of three variables (Benefit 4.1 \& Payment 5). These three factors sum up the dissatisfaction with wages and other benefits. Employees are dissatisfied with their pay or other benefits and believe that this job should be paid more (Spector, 1997; Zaheer, Sharif, Yaqub, \& Baig, 2015).

\subsubsection{Vawork}

Very important factors in this super-variable nature of work (Nature of Work 7.6 \& Value 3). These three factors have in common the feeling of pride, and this can be explained because the customs object is multidimensional.

It contributes to the protection of public health (prosecution and suppression of the trafficking of psychotropic substances, precursors and drugs), public safety (control of the movement of weapons, ammunition and explosives, control of the final destination of Strategic Convention and Technology products), environment (on International Trade in Endangered Species of Wild Fauna and Flora), cultural inheritance (control of illegal outflows of cultural goods), intellectual property rights (counterfeit products, etc.).

Customs also places a great deal of emphasis on "Risk Management" (see this term in Ansell and Wharton (1992)), which is a management technique and a modern tool for selecting controlled goods to target audits based on risk indicators, resulting in fewer and more effective physical controls, and therefore facilitating the flow of trade. In addition, the Customs Service cooperates with agencies within and outside the borders (such as Police, Coast Guard, Interpol, Europol, European Anti - Fraud Office OLAF, World Customs Organization - WCO, SECI Center/ Southeast European Cooperative Initiative to combat cross-border crime etc.), etc.

Therefore, due to the diversity and complexity of the customs object, it makes sense for employees to feel satisfied and proud when they do their job well and protect citizens.

Apart from the purely bureaucratic part of the customs work, then, there is also the prosecution. So, in order to be effective and efficient in their work, these two elements must be well combined, combining many different skills. Andersen and Kjeldsen (2010) demonstrated that job satisfaction depends on both the organizational work and the contribution to society as a whole of each public sector service.

\subsubsection{Paysat}

The sixth factor has high loadings in (Payment 2,3 \& Value 2) and (Promotion 1). It reflects a strong dissatisfaction with the pay, the appreciation of work and opportunity for promotion (Candan, 2013). Employees do not feel that their work is valued when considering their pay and increases, which no longer seem to exist. They also believe that the promotion system does not work effectively, so that at least this contributes to their job satisfaction.

\subsubsection{Paypro}

The seventh and final factor is a combination of three variables (Payment 1,4 \& Benefit 3). These three variables all express a positive attitude towards pay and other work benefits (Candan, 2013; Spector, 1997). This positive attitude, however, is not confirmed by the responses of the customs officials, who expressed strong dissatisfaction at $56.7 \%, 75.2 \%$ and $66.3 \%$ respectively. 


\subsubsection{Reliability test of Cronbach a}

Cronbach's reliability factor informs the researcher of the reliability of the new factors created. Theoretically it can range from o (absolute discrepancy) to 1 (absolute agreement) (only positive values make sense).

If the result is $<0.6$ then it is unreliable. 0.6 is the minimum acceptable limit (but not acceptable for scales with many items), 0.7 is considered sufficient, 0.8 is good and 0.95 is very good (very high reliability), although rare (Ouzouni \& Nakakis, 2011; Siomkos \& Vasilikopoulou, 2005).

Table 26 shows the Cronbach reliability coefficients of the pro-variables that were created:

Table-26.

Index of reliability Cronbach a.

\begin{tabular}{c|c|c}
\hline Hyper-variable & Cronbach Alpha & N of items \\
\hline Partwork & 0.871 & 6 \\
\hline Colman & 0.847 & 5 \\
\hline Eval & 0.832 & 4 \\
\hline Ben.Pay & 0.660 & 3 \\
\hline Vawork & 0.603 & 3 \\
\hline Paysat & 0.453 & 4 \\
\hline Paypro & 0.649 & 3 \\
\hline
\end{tabular}

It is observed that all results are $>0.6$ (minimum acceptable limit) except for the result of the variable Paysat $(0.453<0.6)$ which is unacceptable. The results for the first three hyper-variables (Partwork, Colman, Eval) are $>0.8$, which shows that the reliability of the scale is very high. The other three (Ben.Pay, Vawork, Paypro) are> 0.6 (minimum acceptable limit) and show a reliability acceptable, but not high.

Consequently, it is concluded that there are six (6) hyper-variables, which highlight hidden factors that significantly affect job satisfaction. At the same time, these six (6) hyper-variables demonstrate the connections and relationships in a series of observable-variables.

\section{Discussion}

In a sample of six hundred and seventy-nine (679) participants, from most of the Greek Customs, the findings of this research are particularly important, both in theory and in practice. Detecting the degree of job satisfaction of Greek customs officials, 679 fully answered questionnaires were collected, which provide a satisfactory picture of "what satisfies", "what is dissatisfied" and what "leaves" this group of employees indifferent.

The size of this sample is very important, as about $31 \%$ of current Customs Officers responded, with a response rate of $40 \%$. It should be noted that the special features of the profession, which are many, were taken into account. The size of the sample, the distribution of participants per customs, the positive response of the executives in this research, but also the results, rewarded the researchers for choosing such a much-discussed issue as job satisfaction.

From the first data analysis, the dissatisfaction of the employees with the remuneration they receive and with the other work benefits was evident (identification with Kourakos et al. (2012)). An industry that has lost more than $30 \%$ of its earnings in recent years, it was expected that it would not feel satisfied in this area. An analysis of correlations found that the higher the level of education an employee has, the more frustrated he or she feels about the rewards he or she receives.

Clearly, a high level of education raises expectations for a position (in the private or public sector) that will ensure a high level of pay. Wage cuts in recent years, given the economic crisis, have led many employees to a stalemate, who under the umbrella of security of permanence and a higher salary have created obligations that today, with the new data, they cannot meet and suffocate. 
Relationships with colleagues have been shown to be at a good level. Employees derive satisfaction from interpersonal relationships, although in the question of the communication system opinions differ. Older employees, and therefore older employees, strongly judge younger ones in terms of their skills and interest in the job. Nevertheless, factor analysis demonstrated relationships with colleagues in a very important factor influencing job satisfaction.

Here, satisfaction lies in personal relationships in the work environment. Working in a space with good partners is important. However, developing relationships of trust, appreciation, mutual respect and friendship is more important (Anderfuhren-Biget, Varone, Giauque, \& Ritz, 2010). Man is a "natural social being" according to Aristotle. He needs contact with other people, communication and participation.

The relationship with the supervisor has also been shown to satisfy employees. In general, supervisors need acceptance, both formal and substantive. A competent manager who could provide solutions and answers, support the employee in his own choices, create a climate of mutual aid and support, so that the employee feels safe, leads to high rates of job satisfaction.

Getting the best out of each employee, as well as putting the right person in the right place at the right time, is the result of managerial skills and leadership while also requiring a deep knowledge of the needs and structures of the service.

The supervisor must be clearly positioned towards employees, share roles and responsibilities, clarify any dark spots, and be empowered with enthusiasm and boldness toward a common vision (Voon et al., 2011). Understanding the need for employees, regulations and linking them to industry expectations and vision can only bring positive results for both the organization and job satisfaction of employees (Wright \& Davis, 2003).

The analysis of the results showed that older colleagues (with the most years of service) have a different view from the rest. In particular, they do not consider the supervisors so capable. They believe that they are unfair to them, they are not interested in the Service but also in the feelings they create in their subordinates. This correlation, perhaps, could be explained in the light of age itself. Clearly even a young person could hardly be imposed on a person much older than him (within existing structures).

Until now, the public sector has ranked its employees according to their years of service, mainly, and not based on the formal qualifications they held. Older employees did not easily recognize and accept younger ones, since they had cultivated a very small degree of readiness to change. This, of course, has changed in recent years. Nevertheless, it is the change in the mentality of the employees that will bring about the substantial change and will give a business breath to the public. But that certainly takes time.

It is important to cultivate a quality mentality throughout the organization, so that its members have the maturity and readiness to accept change management models. This, however, requires an excellent channel of communication, respect, appreciation and commitment between the parties involved (colleagues and citizens) (Karyotakis \& Moustakis, 2014).

In the same vein, it is equally important to create an entrepreneurial organizational culture that focuses on human resources, knowledge creation and management, and building relationships of trust between members of the organization, as well as between the organization itself as a whole, and other partners (citizens, other public services, private sector, non-governmental organizations), providing and promoting flexibility, initiative and autonomy, serving the employee, the citizen, the economy and society at large. The above procedures and practices should be accompanied by results-oriented terms, quality, performance, value, transparency, accountability and extroversion (Karyotakis \& Moustakis, 2016).

The research of Bourantas and Papalexandris (1993) demonstrates the limited ability of public administration to monitor, so that there is respect for the hierarchy, to determine the relationship between superiors and subordinates, and to maintain the right distances. The causes are mainly located in the large volume of rules - regulations and bureaucracy. Increasing investment in research and 
education will lead to a change of mindset and a reduction in excessive procedural constraints while employees should be given the opportunity to try (Wright \& Davis, 2003).

Experiments (whether successful or not) are part of the learning process and development of both the individual and the body, and can lead to innovation (Karyotakis \& Moustakis, 2015). The quest for innovation can be successful when an organization behaves rationally and is characterized by a risktaking mentality that rewards experimentation and is accompanied by appropriate skills.

Innovation, in public administration, focuses primarily on changes in relations and political processes, as well as on how to provide public services (Karyotakis \& Moustakis, 2015). It should be noted that daily examples of administrative innovation in public administration are the use of indicators that measure results and evaluate the performance of the services provided (Karyotakis \& Moustakis, 2016).

In general, innovative and entrepreneurial behavior, not only in terms of economic benefit, but more in the light of added value, can lead to a change in behavior and mindset in an organization, promoting creative and innovative thinking (Karyotakis \& Moustakis, 2017).

In public administration, aspects of creating added value can be to improve the quality, efficiency, effectiveness or greater ability to choose and use the services provided (Karyotakis \& Moustakis, 2017) with greater justice, as well as to satisfy the citizen, producing a social footprint and creating a sense of trust (Karyotakis \& Moustakis, 2016). By changing the mindset of outdated bureaucratic processes and perceptions of the public sector, flexibility and innovation can be enhanced by encouraging new ideas.

At the same time, practices and procedures that ensure the quality of services can be maintained (Karyotakis \& Moustakis, 2015). Clearly, public (and not only) organizations need to focus on continuously improving the quality, efficiency and effectiveness of the services and processes provided, as well as the organization as a whole, looking at customer / citizen satisfaction (Karyotakis \& Moustakis, 2014).

The answers of the participants regarding the nature of the job, pleasantly surprised the researchers, since due to this factor, the custom officers enjoy great job satisfaction. Apart from the importance of the factor confirmed by research (Wright \& Davis, 2003) it is one of the key features of the customs object.

Customs officials experience a daily shift in their work that does not allow them to enter a routine and boredom regime. The correlation analysis found that people with higher personal income, more years of service, but also those who hold positions of responsibility, enjoy higher rates of satisfaction through the creation of new ideas, detailed (specific or specialized) work, and a sense of duty towards them fellow human beings.

The results of the present study rank labour participation very high in the factors influencing job satisfaction. There was a positive correlation between the level of education, income, years of service, as well as the job, with all the questions in this category. The results of factor analysis were identified with the above while at the same time shedding more light on the relationships of interconnection and interdependence of variables.

Participating in the team, sharing thoughts, knowledge and experiences, interacting, influencing and emphasizing the opinions of colleagues and business leaders, as well as the leadership role, create an informal evaluation system for each of us (Scarpello \& Campbell, 1983). Self-esteem and self-realization, in most cases, have nothing to do with positions, money and promotions, which in some cases may even outweigh the subjective element over the objective.

However, these values of self-esteem and self-realization are often directly related to the opinion of those around you - colleagues, who in the personal hierarchy of needs (desires) of each are high (informal table of personal evaluation and self-realization) and therefore their opinion is very important. Satisfaction, then, is the greatest, not because it shows someone great in the eyes of others (social recognition), but because it values him towards himself (satisfaction of the inner ego).

It should be noted once again that the specificity of the customs object is commonly accepted. The customs officer is not a simple office clerk, with only executive duties. Most of the time, mainly in small 
Customs, due to the many and different jobs (but also in larger ones, due to insufficient staffing, shifts and emergencies, which are frequent), an employee can perform many different jobs at the same time. It is jokingly said that a customs officer can be "from a cleaner to a manager".

The objects of persecution and control (such as the free delivery of fuel to boats, the free shipping on ships, etc.), require the physical presence of the employee at the border, at the port, at the pier and in many other places outside the office. This constant movement and daily shift do not allow the employee to relax for a minute, but at the same time removes him from situations of routine, boredom and boredom (Wright \& Davis, 2003).

The daily invention of new practices and methods to improve working conditions (which are usually not so easy, and in fact are possessed by several peculiarities) and its results, hide a dynamic that if used properly can lead to win-win results. win for state employees - citizens (Kaiser, 2014).

The way in which it is evaluated, but also the perspectives in which it leads to the conquest of a higher job (with all that entails), has become a very important factor in job satisfaction. In addition, each employee develops perceptions of "procedural justice", which focuses on the correctness of the procedures and means used to evaluate employees.

In particular, research by Cotton and Tuttle (1986), as well as Hom and Griffeth (1991) show that job satisfaction and dedication can provide a possible way out of work (escape or flight). At this point it should be noted that the objectivity of the evaluation criteria, the acceptance of the people who will be appointed to this role, as well as the inviolability of the procedures, have been of great concern to all civil servants lately, perhaps more than ever.

The public administration follows, for the most part, a centralized system and until relatively recently operated bureaucratically. Customer relations were intervened in the evaluation methods and practices and there were black spots. This recent past has been etched in the minds of many civil servants, who are sceptical, hesitant and doubt the quality, efficiency and effectiveness of any new evaluation system. These data, combined with the international socio-economic developments, due to pandemics and other phenomena, have created an environment of uncertainty, more general and more specific in public administration, burdening employees with insecurity and confusion.

\section{Limitations}

Concluding this research, it would be appropriate to mention some of the limitations that exist. A very important limitation is that in the empirical part of this research, the job satisfaction of Greek customs officials was sought and analyzed only. In other words, the present study concerns a case study, so this does not allow its results to be safely generalized to all civil servants in Greece.

Weaknesses could also be considered the fact that data collection was based on individuals who responded voluntarily (Karyotakis \& Moustakis, 2017). Thus, the information obtained, although valuable, needs to be thoroughly interpreted in order to avoid common mistakes (e.g., socially acceptable) related to the respondent (Polit \& Beck, 2004). Therefore, there may be a common method variance (Podsakoff, MacKenzie, Lee, \& Podsakoff, 2003).

In addition, in the process of collecting the questionnaires, a reservation was made as to the preservation of anonymity. Some participants were observed enclosing the questionnaire in an individual blank envelope and handing it over to the Customs Secretariats, so that they could be sent in their entirety.

A limitation is also the fact that a specific measuring tool was used. Perhaps there are other aspects of job satisfaction that would help to better understand perceptions and work attitudes regarding job satisfaction. Also, the results of the research may have been influenced by external variables, which were not included in the study or is susceptible to reverse causality (Backhaus, Erichson, Plinke, \& Weiber, 2015). Thus, the nature of the data limits the type of conclusions and methods of analysis.

With regard to the 7-point Likert scale used in the present study, it should be noted that this scale itself may pose some risks. E.g. due to its size, combined with the volume of questions, it could create 
confusion among respondents. Also, there is still the fact that it cannot be verified that all those who state the same answer mean the same thing (Karyotakis, 2019).

Although assumptions are based on theoretical factors and theoretical considerations, the relationships identified could be the basis for mechanisms different from those taken into account and assumed (Karyotakis, 2019).

In the future, it would be interesting to investigate job satisfaction, using even more variables, in all branches of the Independent Public Revenue Authority (which now includes the customs, and not in the Ministry of Finance, as before) or the wider public sector, representing thus greater diversity of demographic groups.

Questionnaires could also be combined with Customs officials, supervisors and traders, crossreferencing data to measure the satisfaction citizens receive through service, training and courtesy of employees and supervisors. Through a feedback process between employees, supervisors and business people, it could be confirmed whether the self-reports of ordinary executives, supervisors and citizens are accurate or contain prejudices and support bias.

A generalized survey, in the European Union Customs, governed by 01/05/2016 by common rules (Regulation EU No. 952/2013, Union Customs Code), could examine similarities and differences at all levels, as well as export safely and general conclusions on the employment satisfaction of customs officials in Europe Union.

\subsection{Instead of an Epilogue}

In kind of a conclusion, at a time when the world is flooded with constant changes in labour, politics, economy and society, experiencing the economic crisis in all its stages and manifestations, with an economy plunged into recession and citizens in a state of turmoil. Uncertainty, confusion and fear, there is the possibility by activating some, mainly endogenous motivations, to achieve job satisfaction, without putting your hand in your pocket (Crewson, 1997).

In this regard, it is very important to carry out timely and valid management of any change (change management), creating the appropriate mentalities (individual and organizational), so that all available resources of an organization are optimally utilized and placing the right person, in appropriate location, at the right time. This research, therefore, aims at a better understanding of the issues under consideration and encourages future discussions on them. Of course, it becomes clear that no dimension or factor can fully satisfy the human being: because satisfaction is a state of ... mind!

\section{References}

Acito, F., Anderson, R. D., \& Engledow, J. L. (1980). A simulation study of methods for hypothesis testing in factor analysis. Journal of Consumer Research, 7(2), 141-150. Available at: https://doi.org/10.1016/0304-405x(95)00844-5.

Anderfuhren-Biget, S., Varone, F., Giauque, D., \& Ritz, A. (2010). Motivating employees of the public sector: does public service motivation matter? International Public Management Journal, 13(3), 213-246. Available at: https://doi.org/10.1080/10967494.2010.503783.

Andersen, B. L., \& Kjeldsen, A. M. (2010). How public service motivation affects job satisfaction: A question of employment sector or 'public service jobs. Paper presented at the 32nd EGPA Annual Conference PhD Symposium Meeting of EGPA Permanent Study Groups, Touluse, France, 8-10 September, 3-18.

Ansell, J., \& Wharton, F. (1992). Risk management: A review. Risk: Analysis, Assessment and Management (pp. 203-2 11 ): John Wiley \& Sons Incorporated.

Aronson, K. R., Laurenceau, J.-P., Sieveking, N., \& Bellet, W. (2005). Job satisfaction as a function of job level. Administration and Policy in Mental Health and Mental Health Services Research, 32(3), 285-291. Available at: https://doi.org/10.1007/s 10488-004-0845-2.

Backhaus, K., Erichson, B., Plinke, W., \& Weiber, R. (2015). Multivariate analysemethoden: Eine anwendungsorientierte einführung. Berlin, Germany: Springer Gabler.

Batiou, V., \& Valkanos, E. (2013). Job satisfaction of public administrative personnel in Greece. International Journal of Academic Research in Business and Social Sciences, 3(1), 1-11. Available at: https://doi.org/10.6007/IJARBSS/v3-i 11/336.

Bourantas, D., \& Papalexandris, N. (1993). Differences in leadership behaviour and influence between public and private organizations in Greece. International Journal of Human Resource Management, 4(4), 859-871. Available at: https://doi.org/10.1080/09585199300000061.

Brislin, R. W., Lonner, W., \& Thorndike, R. (1973). Cross-cultural research methods. New York: Wiley. 
Candan, H. (2013). A research towards determination of job satisfaction level of public employees: Karaman governorship sample. Journal of Human Resource Management, 1(2), 29-38. Available at: https://doi.org/10.11648/j.jhrm.20130102.11.

Cotton, J. L., \& Tuttle, J. M. (1986). Employee turnover: A meta-analysis and review with implications for research. Academy of Management Review, 11(1), 55-70. Available at: https://doi.org/10.2307/258331.

Crewson, P. E. (1997). Public-service motivation: Building empirical evidence of incidence and effect. Journal of Public Administration Research and Theory, 7(4), 499-518. Available at: https://doi.org/10.1093/oxfordjournals.jpart.a024363.

Davis, R. S. (2013). Unionization and work attitudes: How union commitment influences public sector job satisfaction. Public Administration Review, 73(1), 74-84. Available at: https://doi.org/10.1111/j.1540-6210.2012.02609.x.

Devi, S., \& Suneja, A. (2013). Job satisfaction among bank employees: A comparative study of public sector and private sector banks. International Journal of Research in Management, Science and Technology, 1(2), 93-101.

Eyupoglu, S. Z., \& Saner, T. (2009). The relationship between job satisfaction and academic rank: A study of academicians in Northern Cyprus. Procedia-Social and Behavioral Sciences, 1(1), 686-691. Available at: https://doi.org/10.1016/j.sbspro.2009.01.120.

Gibbon, B. (1995). Validity and reliability of assessment tools. Nurse Researcher, 2(4), 48-55. Available at: https://doi.org/10.7748/nr.2.4.48.s6.

Hair, J. F., Black, W. C., Babin, B. J., Anderson, R. E., \& Tatham, R. L. (2006). Multivariate data analysis (Vol. 6). Upper Saddle River, NJ: Pearson Prentice Hall.

Hom, P. W., \& Griffeth, R. W. (1991). Structural equations modeling test of a turnover theory: Cross-sectional and longitudinal analyses. Journal of Applied Psychology, 76(3), 350. Available at: https://doi.org/10.1037/00219010.76.3.350.

Kaiser, L. C. (2014). Job satisfaction and public service motivation (pp. 4-15). IZA DP No. 7935.

Karyotakis, K. M., \& Moustakis, V. S. (2014). Reinvention of the public sector: Total quality management and change management. The European Journal of Applied Economics, 11(2), 30-44. Available at: https://doi.org/10.5937/sjas 1 16751.

Karyotakis, K. M. (2019). Methodological framework and empirical analysis on entrepreneurship and innovation in the public sector (Doctoral dissertation). Technical University of Crete, Greece. In Greek.

Karyotakis, K. M., \& Moustakis, V. S. (2015). Innovating in public administration. Paper presented at the 12th Student Conference of Science and Technology, Athens University of Economics and Business \& Hellenic Management Association, Athens, Greece, 14 May In Greek.

Karyotakis, K. M., \& Moustakis, V. S. (2017). Methodological framework on entrepreneurial orientation and innovation in the public sector. Sinteza, Singidunum University. Paper presented at the International Scientific Conference on Information Technology and Related Research, Belgrade, Serbia, .

Karyotakis, K. M., \& Moustakis, V. S. (2016). Organizational factors, organizational culture, job satisfaction and entrepreneurial orientation in public administration. The European Journal of Applied Economics, 13(1), 47-59.

Kourakos, M., Kafkia, T., Rekliti, M., Zyga, S., Kotrotsiou, E., \& Gouva, M. (2012). A job satisfaction study among healthcare professionals-nurses in medical wards in the Greek National Health System. Archives of Hellenic Medicine/Arheia Ellenikes Iatrikes, 29(1), 61-69.

Martin, W. S. (1978). Effects of scaling on the correlation coefficient: Additional considerations. Journal of Marketing Research, 15(2), 304-308. Available at: https://doi.org/10.2307/3151268.

Mitchell, R. (1966). The problems and possibilities of measuring social attitudes in African social surveys. Paper presented at the In ninth annual meeting of the African Studies Association, Bloomington, Indiana.

Ntio, D. D. (2004). The application of factor analysis in marketing (pp. 10-18). Chios, Greece. In Greek: University of Aegean.

Ouzouni, C., \& Nakakis, K. (2011). Validity and reliability of measurement instruments in quantitative studies. Nursing, 50(2), 231-239.

Park, S. M., \& Rainey, H. G. (2007). Antecedents, mediators, and consequences of affective, normative, and continuance commitment: Empirical tests of commitment effects in federal agencies. Review of Public Personnel Administration, 27(3), 197-226. Available at: https://doi.org/10.1177/0734371x06296866.

Podsakoff, P. M., MacKenzie, S. B., Lee, J.-Y., \& Podsakoff, N. P. (2003). Common method biases in behavioral research: a critical review of the literature and recommended remedies. Journal of Applied Psychology, 88(5), 879-903. Available at: https://doi.org/10.1037/002 1-9010.88.5.879.

Polit, D. F., \& Beck, C. T. (2004). Nursing research: Principles and methods (7th ed.). Philadelphia: Lippincott Williams \& Wilkins.

Scarpello, V., \& Campbell, J. P. (1983). Job satisfaction: Are all the parts there? Personnel Psychology, 36(3), 577-600.

Schuman, H. (1966). The random probe: A technique for evaluating the validity of closed questions. American Sociological Review, $31(2), 218-222$. Available at: https://doi.org/10.2307/2090907.

Siomkos, G., \& Vasilikopoulou, A. I. (2005). Application of analysis methods in market research (pp. 285-312). Athens: Stamoulis Publications.

Smye, M., \& Cooke, R. (1994). The key to corporate survival: Change begins and ends with people. In L.A. Berger, M.J. Sikora, E゚ D.R. Berger (Ed.), The change management handbook: A road map to corporate transformation. New York: McGraw-Hill.

Spector, P. E. (1997). Job satisfaction: Application, assessment, causes, and consequences. Thousand Oaks, CA: Sage.

Spector, P. E. (1994). Job satisfaction survey. Tampa, FL: Department of Psychology, University of South Florida. 
Stewart, D. W. (1981). The application and misapplication of factor analysis in marketing research. Journal of Marketing Research, 18(1), 51-62. Available at: https://doi.org/10.2307/3151313.

Tabachnick, B. G., \& Fidell, L. S. (2011). Multivariate analysis of variance (MANOVA). In Lovric M. (Eds), International encyclopedia of statistical science (Vol. 13, pp. 902-904). Berlin, Heidelberg: Springer.

Voon, M. L., Lo, M. C., Ngui, K. S., \& Ayob, N. B. (2011). The influence of leadership styles on employees' job satisfaction in public sector organizations in Malaysia. International Journal of Business, Management and Social Sciences, 2(1), $24-32$. Available at: https://doi.org/10.2307/3151313.

Werner, O., \& Campbell, D. T. (1970). Translating, working through interpreters and the problem of decentering. In R. N. Cohen and R. Cohen (eds.), A handbook of method in cultural anthropology. New York: American Museum of Natural History.

Wright, B. E., \& Davis, B. S. (2003). Job satisfaction in the public sector: The role of the work environment. The American Review of Public Administration, 33(1), 70-90. Available at: https://doi.org/10.1 177/0275074002250254.

Zaheer, N., Sharif, M. T., Yaqub, R. M. S., \& Baig, F. J. (2015). Factors affecting job satisfaction at public sector secondary schools of Rahim Yar Khan. Developing Country Studies. 5(5), 27-68.

Zampetakis, L. A. (2007). Methodology for the development of entrepreneurship in public sector. (Doctoral Dissertation). Technical University of Crete, Greece.

Journal of Contemporary Research in Social Sciences
ISSN : 264.1-0249
Vol. 2, No. 5, pp. $89-118,2020$
DOI: $10.33094 / 26410249.2020 .25 .89 .118$
C) 2020 by the authors; licensee Learning Gate

